\title{
Does temporal and locational flexibility of work increase the supply of working hours? Evidence from the Netherlands
}

\author{
Daniel Possenriede ${ }^{1,2^{*}}$ (D) Wolter H.J. Hassink ${ }^{1,2}$ and Janneke Plantenga ${ }^{1}$
}

\author{
${ }^{*}$ Correspondence: \\ d.possenriede@uu.n \\ 1 Utrecht University School of \\ Economics, P.O. Box 80125, 3508 TC \\ Utrecht, The Netherlands \\ ${ }^{2}$ IZA, Bonn, Germany
}

\begin{abstract}
In recent years, many employees have gained more control over temporal and locational aspects of their work via a variety of flexible work arrangements, such as flexi-time and telehomework. This temporal and locational flexibility of work (TLF) is often seen as a means to facilitate the combination of work and private life. As such it has been recommended as a policy to increase the average number of working hours of part-time workers. To the best of our knowledge, the effectiveness of this policy instrument has not been tested empirically yet. We therefore analyse whether flexi-time and telehomework arrangements increase the number of actual, contracted, and preferred working hours. Based on Dutch household panel data, our results indicate that the link between TLF and working hours is quite weak. Telehomework is associated with moderate increases in actual hours, but not in contracted or preferred hours. Flexi-time generally does not seem to be associated with an increase in hours worked. Despite positive effects on job satisfaction and working time fit, we do not find any convincing evidence of a positive effect of TLF on labour supply.
\end{abstract}

JEL classification: J22, J32, M52, M54

Keywords: Flexi-time, Labour supply, Locational flexibility, Part-time work, Telehomework, Temporal flexibility

\section{Introduction}

In recent years, many employees have gained more control about when, where, and how long they work. This temporal and locational flexibility of work (TLF), which facilitates employees with flexibility in the schedule, location, and duration of their work, is usually implemented via a variety of flexible work arrangements, such as flexi-time, selfscheduling, and telehomework (Fagan 2004; Hill et al. 2008; Plantenga 2003; Rau 2003). This development has been fostered by an increasing relevance of knowledge work and the service industries in general, by new forms of work organisation, but in particular by the proliferation of information and communication technology (ICT), which has facilitated asynchronous and remote exchange of information.

In many debates, TLF is primarily viewed as a means to combine work and private life and consequently has become highly topical in the policy debate in a number of countries (see, e.g. CEA 2010; BMFSFJ 2012). As such, TLF arrangements have also become a common policy recommendation to increase labour supply in order to increase economic

(c) 2016 The Author(s). Open Access This article is distributed under the terms of the Creative Commons Attribution 4.0 International License (http://creativecommons.org/licenses/by/4.0/), which permits unrestricted use, distribution, and reproduction in any medium, provided you give appropriate credit to the original author(s) and the source, provide a link to the Creative Commons license, and indicate if changes were made. 
growth and to prevent labour force shortages in the future (Rürup and Gruescu 2005; Sociaal-Economische Raad 2011; Taskforce DeeltijdPlus 2010). In environments with relatively high labour force participation rates and a lot of (female) part-time workers, the main focus is on increasing the number of working hours with more TLF. It has not, to the best of our knowledge, been tested empirically yet, whether this supposed link between TLF and increasing working hours actually holds, however.

The aim of this paper is therefore to analyse whether and to what extent TLF arrangements indeed influence labour supply. In particular, we analyse the impact of TLF arrangements that provide schedule and location flexibility on the number of actual, contracted, and preferred working hours. The analysis is carried out on the basis of a Dutch household panel dataset. The Netherlands are a good test case in this context, because they are a highly developed service society with an excellent ICT infrastructure, which means that the scope for TLF is relatively high. Increasing working hours of parttime employees has been a policy concern for some years now (Sociaal-Economische Raad 2011; Taskforce DeeltijdPlus 2010), and the Dutch labour market is quite flexible already. Employees in the Netherlands have a legal right to both decrease and increase their contracted working hours for example. ${ }^{1}$ Obstacles to adjust working hours are therefore comparatively low, and contracted hours should adapt relatively quickly to new conditions, also within existing employment relations.

Our results indicate that the association between TLF and working hours is quite weak. Telehomework is associated with moderate increases in actual hours, but not in contracted or preferred hours, which implies that telehomework is primarily associated with more overtime. Flexi-time generally seems to have an ambiguous effect on working hours. So despite positive effects on job satisfaction and working time fit (see e.g. Possenriede and Plantenga 2014), we do not find any convincing evidence of a positive effect of TLF on labour supply.

\section{Theoretical framework}

Female labour force participation rates have increased tremendously in the Netherlands in the last two decades. In recent years, they have been around $73 \%$ and thus eight to ten percentage points above EU average. Average weekly working hours of females, however, have stagnated at a relatively low 25 hours per week (see Fig. 1). Part-time work is used extensively to combine work and private life in the Netherlands-private life here referring to any other responsibility, activity, or event that is not paid work. The resulting low

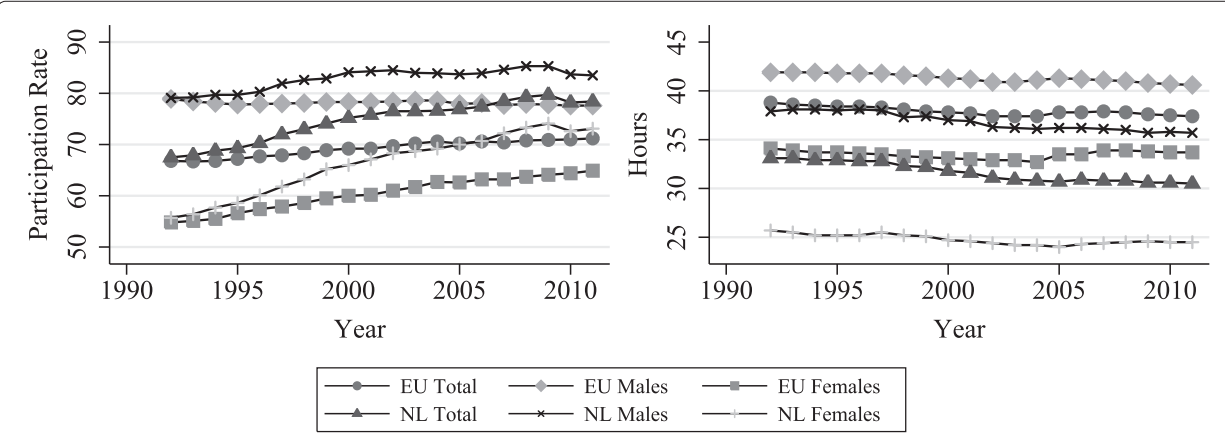

Fig. 1 Participation rates and average working hours in the EU and the Netherlands, 1992-2011 
number of weekly and annual working hours is considered to be problematic in the face of an ageing society, the expected labour force shortages, gender equality, and low economic growth in general. Various policy initiatives to increase female labour supply at the intensive margin have therefore been undertaken, among which calls for more temporal and locational flexibility. The idea is that more TLF and thus more control over working hours will improve work-life fit and induce employees to supply more hours to the labour market. As a result, arrangements such as flexi-time and telehomework can to some extent substitute part-time work as a means to reconcile work and private life.

The notion that more TLF may lead to an increase in labour supply has been supported by surveys in which a considerable share of respondents report that they would be willing to supply more hours to the labour market if more flexibility options were available. In a 2009 survey for example, 35-41 \% of non-participants and 25-39 \% of part-time workers responded that more flexibility would be an important condition to either participate in or supply more hours to the labour market, respectively (Cloïn et al. 2010). The conditions mentioned include better reconciliation of working times and private life, finding a job with the preferred number of hours, working part of the week from home, being able to take a day off if a family member gets sick, and finding a job closer to home. If these responses are sincere, more temporal and locational flexibility and a better fit between work and private life should indeed raise labour supply.

In theory, two potential channels can lead from increased flexibility to more working hours. The first one concerns a decrease in commuting time, the second a reduction of schedule constraints and a better match between work and private schedules.

Although commuting can be seen as a prerequisite for paid work, commuting time per $s e$ is unproductive and inefficient. Commuting time can be reduced with flexible working times, because it is possible to avoid rush hour traffic by commuting at less busy times. Commuting can even be eliminated altogether when one is working at home. This time gain can then be spent at work. ${ }^{2}$

While the theoretical predictions are to some extent dependent on the assumptions made, a simple model predicts exactly this. ${ }^{3}$ In a graphical representation (Fig. 2), $C$ designates the consumption of goods, $L$ the consumption of leisure, and $L_{0}$ maximum

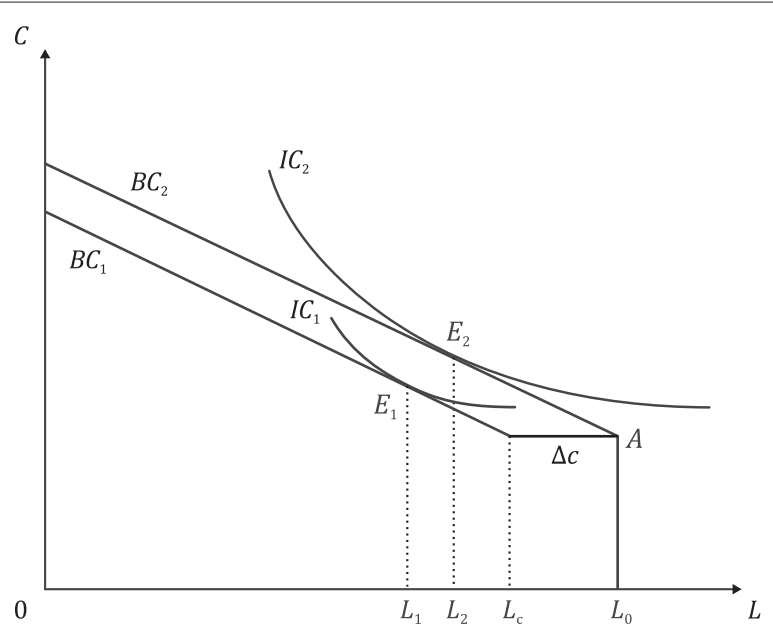

Fig. 2 Commuting and labour supply 
time available. The line $L_{0} A$ designates non-labour income, $I C$ is the indifference curve, corresponding to the level of utility obtained by the individual, and $B C$ is the budget line with slope $w$, the wage rate. If time has to be spent on commuting, the optimal solution is situated at the tangency point $E_{1}$ of the indifference curve with the budget constraint $B C_{1}$. Here, the individual would supply $L_{1} L_{c}$ hours on labour, spend $L_{c} L_{0}=\Delta c$ on commuting, and enjoy $0 L_{1}$ hours of leisure. ${ }^{4}$

If commuting is eliminated, the budget constraint shifts to the right and utility increases. The optimal solution is now at $E_{2}$ and leisure time increases by $L_{1} L_{2}$. At the same time, labour supply increases by $\Delta c-L_{1} L_{2}$ and is now $L_{2} L_{0}$. Part of the time gain due to a reduction in commuting time will thus be spent on additional labour supply. This result holds unambiguously if we assume leisure and consumption to be normal goods (Black et al. 2014). ${ }^{5}$

The existing empirical evidence, however, suggests that the size of the effect of TLF due to commuting time savings alone is likely to be limited. While there is little direct evidence on the effects of commuting costs on labour supply, indirect evidence (e.g. that commuters seem to attach relatively low value to travel time) suggests that the effect of the length of the commute on labour supply is rather weak (Gibbons and Machin 2006). More recently, Gutiérrez-i-Puigarnau and van Ommeren (2010) even found a small positive effect of commuting on the number of daily and weekly working hours.

A second channel via which more temporal and locational flexibility can lead to an increase in labour supply is a reduction of schedule constraints and a better match between schedules of work and private life. Tasks and events of both paid work and private life are not distributed randomly over the day and week. Most of the time, they take place within defined schedules, because in both spheres workers depend on and interact with other individuals. Work is usually carried out in teams within and across firms and many workers deal directly with clients and business partners. Goods and services have to be produced and handled at specific times because they are expected by other workers in the production chain, clients expect them at specific times (e.g. during opening and business hours), or because the goods and services involved are perishable or otherwise time-critical. In addition, working hours and schedules are generally limited due to legal restrictions and social norms. As a result, workers are often constrained in the choice of their working schedule.

In the same vein, the timing of leisure tasks and activities often depend on others. The schedules of working parents for example depend on their children's daycare and school schedules. Informal care often has to be performed at specific times of the day (Hassink and van den Berg 2011). Stores, businesses, and public and health services have limited business and opening hours. Further education classes and recreational activities (sports, clubs, etc.) take place at designated times. Since daycare, school, office, and service hours usually cannot be altered by individual workers, they constitute a binding schedule constraint.

Both work and leisure activities thus impose a schedule constraint on workers, meaning that these activities can only be performed at specific times or within a specified time frame. Activities therefore have to be coordinated and their schedules matched. This matching can be achieved more easily the more flexible and controllable schedules are. More flexibility in work schedule and location should therefore improve the fit between work and leisure activities, prevent and eliminate time conflicts, and improve allocative 
efficiency (Bosch et al. 1994; Golden 2006). TLF has accordingly been shown to increase working-time fit and job satisfaction (Possenriede and Plantenga 2014).

The trade-off between working hours and schedules is easily illustrated with an extension of the standard labour supply model (Golden 1996; 2006). According to the standard model, an individual's well-being is determined by his or her consumption and hours of leisure. This is represented by a utility function $(U)$ with the standard consumption $(C)$ and leisure $(L)$ arguments. But since utility from work is also dependent on work schedule, location, and their flexibility, we add a schedule parameter $(S)$ to the utility function:

$$
U=U[C, L, S]
$$

$S$ represents both the schedule and location of work as well as their adaptability. Based on the considerations above, we assume that work schedules and locations that fit in well with leisure activities provide more utility than those that do not. In addition, flexible schedules and locations provide more utility than inflexible ones, because they are more adaptable to changing circumstances for instance. Note that this is not much different from the usual assumptions about consumption and leisure in standard labour economics. Just like we assume that consumption and leisure are normal goods, i.e. that more consumption and more leisure "is better" in the sense that it provides more utility, we assume here that more flexibility in work schedule and location (i.e. more control over timing and location of work) and thus a better schedule and working time fit "is better" as well.

It follows that utility is strictly increasing and marginal utility decreasing in all arguments:

$$
\frac{\partial U}{\partial C}, \frac{\partial U}{\partial L}, \frac{\partial U}{\partial S}>0 ; \quad \frac{\partial^{2} U}{\partial C^{2}}, \frac{\partial^{2} U}{\partial L^{2}}, \frac{\partial^{2} U}{\partial S^{2}} \leq 0
$$

Under these general assumptions, workers should be willing to trade leisure time or income for more flexibility and vice versa (Golden 2006). ${ }^{6}$

We need to keep in mind, though, that consumption potentially is another channel via which a trade-off with TLF might take place. Instead of increasing labour supply, workers may be willing to trade part of their wage or future wage increases for increased flexibility and better work schedules (Altonji and Paxson 1988; Baughman et al. 2003; Heywood et al. 2007). This will be addressed in the empirical analysis by controlling for wage.

Based on these considerations, we arrive at the following hypothesis:

Hypothesis. More temporal and locational flexibility of work is associated with an increase in hours worked.

There are a few reasons to believe, however, that the overall impact of TLF on working hours is limited and may even be negative in the aggregate.

Employees may for example not be willing to increase labour supply but may just as well enjoy their improved work-life fit from increased TLF. Labour market imperfections may allow them to do so, since TLF seems to be primarily distributed among higher-status jobs with possibly less supply side competition (Felstead et al. 2002; Golden 2008; 2009; Smulders et al. 2011). Norms and societal preferences may reinforce this trend further, in the sense that work norms have eroded due to proliferation of part-time work in the Netherlands (Wielers and Raven 2013) and that it is therefore not "attractive" to increase working hours (see, e.g. Bosch et al. 2010; Booth and van Ours 2013). Furthermore, telehomework may partly be used to just transfer some work home, so working time at the 
office is substituted for working time at home (Noonan and Glass 2012; Peters and van der Lippe 2007).

TLF may also impose externalities on an employee's partner at home and colleagues at work. From a household perspective, an increase in the number of hours (due to the availability of TLF or otherwise) may at least partially be compensated by a reduction in the hours of the partner. At work, there may be a trade-off between the match between the schedules of work and private life for one employee and the match between work schedules of several colleagues. To improve the latter, fixed schedules may act as a coordination device. So even if TLF is generally available at a workplace, an employee may de facto not be able to make use of it. Similarly, it might not be viable in certain jobs to supply more hours, if those hours can only be supplied late in the evening, on weekends, or at home for example, because those particular jobs require constant interaction with colleagues or clients.

TLF may finally not be viewed as a means of more control by the employee, if the utilisation of TLF is imposed by the employer in order to increase operating hours or save on office space for example. So the mere availability of TLF arrangements may not necessarily imply a better fit between work and private life.

The question of whether TLF increases the supply of working hours is therefore essentially an empirical matter. One that we are trying to solve in the following sections.

\section{Data and variable description}

The data for the analysis is taken from the Dutch Labour Supply Panel (Arbeidsaanbodpanel, AAP), a biennial panel survey of a representative sample of Dutch households (Sociaal en Cultureel Planbureau (SCP) 2015). ${ }^{7}$ The panel survey is conducted to study developments in labour market behaviour and working conditions in the Netherlands and covers a broad range of work- and life-course-related items. The target population consists of the Dutch labour force aged 16 to 66 years. The AAP has existed since 1985, but questions about (tele)homework were first asked in 2002, so only the waves from 2002 onwards are suitable for an analysis of TLF. This means that we have six waves available for this analysis, for every other year since 2002 to the last publicly available wave from 2012. We restrict the sample to employees (i.e. we exclude self-employed, unemployed, full-time students, etc.), which results in an unbalanced panel of 20,452 observations from 8720 individuals.

We use flexi-time and telehomework as indicators for TLF. The flexi-time variable was obtained from the following survey question:

"Can you say whether each of the following characteristics does or does not apply to the work you do? [...] Determine start- and end-time myself"

The telehomework variable was obtained from the following question:

"Do you work at home every now and then in your current job?"8

We only count those respondents as telehomeworkers who state that they work at home at least once a week on average. ${ }^{9}$ On average, $39 \%$ of the respondents in the sample can determine the start- and end-times of their work and $18 \%$ work at home at least once a week. The shares of flexi-timers and telehomeworkers are generally larger for male than for female employees (see Table 1). Over the six waves, 1188 respondents change their 
Table 1 Share of flexi-time and telehomework by year and gender

\begin{tabular}{|c|c|c|c|c|c|c|c|}
\hline & \multicolumn{2}{|l|}{ Male } & \multicolumn{2}{|c|}{ Female } & \multicolumn{2}{|l|}{ Total } & \multirow[t]{2}{*}{ N } \\
\hline & $\%$ & S.E. & $\%$ & S.E. & $\%$ & S.E. & \\
\hline \multicolumn{8}{|c|}{ Flexi-time } \\
\hline 2002 & 36.41 & $(1.57)$ & 26.72 & $(1.41)$ & 31.51 & $(1.07)$ & 1952 \\
\hline 2004 & 45.54 & $(1.28)$ & 34.37 & $(1.37)$ & 40.57 & $(0.95)$ & 2748 \\
\hline 2006 & 43.46 & $(1.25)$ & 33.52 & $(1.26)$ & 38.75 & $(0.91)$ & 3035 \\
\hline 2008 & 47.92 & $(1.27)$ & 34.73 & $(1.24)$ & 41.56 & $(0.90)$ & 3073 \\
\hline 2010 & 44.01 & $(1.40)$ & 33.12 & (1.34) & 38.60 & (0.99) & 2518 \\
\hline 2012 & 48.67 & $(1.37)$ & 34.50 & $(1.31)$ & 41.62 & $(0.98)$ & 2696 \\
\hline Total & 44.81 & $(0.83)$ & 33.12 & $(0.81)$ & 39.18 & $(0.60)$ & 16,022 \\
\hline \multicolumn{8}{|c|}{ Telehomework } \\
\hline 2002 & 15.98 & (1.19) & 13.16 & $(1.09)$ & 14.55 & $(0.82)$ & 1952 \\
\hline 2004 & 17.37 & $(0.97)$ & 14.98 & $(1.02)$ & 16.30 & $(0.73)$ & 2748 \\
\hline 2006 & 18.79 & $(0.98)$ & 16.62 & $(0.98)$ & 17.76 & $(0.71)$ & 3035 \\
\hline 2008 & 20.19 & $(1.01)$ & 18.54 & $(1.01)$ & 19.39 & $(0.74)$ & 3073 \\
\hline 2010 & 19.72 & $(1.12)$ & 17.84 & $(1.08)$ & 18.78 & $(0.80)$ & 2518 \\
\hline 2012 & 20.83 & $(1.10)$ & 18.93 & $(1.08)$ & 19.88 & $(0.78)$ & 2696 \\
\hline Total & 18.94 & $(0.63)$ & 16.88 & $(0.64)$ & 17.95 & $(0.47)$ & 16,022 \\
\hline
\end{tabular}

flexi-time and 845 change their telehomework status (i.e. they were, e.g. working at home in at least one wave and not working at home in another). The availability and use of flexi-time and telehomework varies greatly across sectors (see Table 2). This suggests that job-related factors play an important role here.

We use actual, contracted, and preferred hours as outcome variables. Prior research has found a positive relationship between telehomework and hours worked (Eldridge and Wulff Pabilonia 2008; Noonan and Glass 2012; Peters and van der Lippe 2007). This has been mainly attributed to an increase in work demands and overtime, as well as an expansion of the standard working week via an increase in actual hours (Noonan and Glass 2012; Peters and van der Lippe 2007). If only actual and (unpaid) overtime hours increase but contracted and preferred hours do not, workers may not benefit from the increase in working hours through higher income (assuming that the hourly wage would stay the

Table 2 Flexi-time and telehomework by sector

\begin{tabular}{|c|c|c|c|c|c|}
\hline \multirow[t]{2}{*}{ Sector } & \multicolumn{2}{|c|}{ Flexi-time } & \multicolumn{2}{|c|}{ Telehomework } & \multirow[t]{2}{*}{ N } \\
\hline & $\%$ & S.E. & $\%$ & S.E. & \\
\hline Agriculture & 32.31 & $(4.12)$ & 6.92 & $(2.23)$ & 130 \\
\hline Industry & 39.13 & $(1.12)$ & 10.71 & $(0.71)$ & 1886 \\
\hline Construction & 31.02 & $(1.74)$ & 10.48 & $(1.15)$ & 706 \\
\hline Trade, gastronomy, repair & 24.25 & $(0.92)$ & 8.47 & $(0.60)$ & 2173 \\
\hline Transport & 31.59 & $(1.47)$ & 6.72 & $(0.79)$ & 997 \\
\hline Business services & 55.20 & $(0.95)$ & 19.83 & $(0.76)$ & 2743 \\
\hline Care, welfare & 30.44 & $(0.80)$ & 14.16 & $(0.61)$ & 3285 \\
\hline Other services & 44.19 & $(1.83)$ & 19.73 & $(1.46)$ & 740 \\
\hline Government & 67.21 & $(1.18)$ & 16.21 & $(0.92)$ & 1592 \\
\hline Education & 29.66 & $(1.09)$ & 52.37 & (1.19) & 1770 \\
\hline Total & 39.18 & $(0.39)$ & 17.95 & $(0.30)$ & 16,022 \\
\hline
\end{tabular}

Note: Share of employees with flexi-time and telehomework by sector

S.E. standard error of the mean 
same after an increase in contracted hours). Furthermore, the work-life fit of employees may not increase but rather decrease if preferred hours stay the same. We therefore not only analyse the impact of TLF on actual working hours but consider contracted and preferred hours as well.

The actual (only available from 2004 onwards) and contracted hour variables were obtained from the following survey questions:

"How many hours per week do you actually work on average?" and

"How many hours do you work according to your contract? Overtime-hours should not be considered."

The preferred hours variable was derived from the following question:

"Are you satisfied with the current number of contract hours or would you like to work more or fewer hours? Take into account that your hourly wage does not change and that others in your household will not work more or fewer hours." The answer categories are as follows: "Yes, satisfied with hours; No, I would like to work $X$ MORE hours per week; No, I would like to work $X$ FEWER hours per week."

Contracted hours were used as the basis for the preferred hours variable, to which $X$ hours were added or subtracted depending on whether respondents indicated that they wanted to work more or fewer hours. On average, employees in the sample actually work $33.63 \mathrm{~h}$ (39.66 and $27.05 \mathrm{~h}$ for male and female employees, respectively, see Table 3). Contracted hours are a little lower at $31.12 \mathrm{~h}$ (36.58 $\mathrm{h}$ for males and $25.24 \mathrm{~h}$ for females). Preferred hours are again slightly lower but have been slowly increasing for female employees in the period under consideration (from $23.74 \mathrm{~h}$ in 2002 to $25.43 \mathrm{~h}$ in 2012; not shown).

In order to rule out confounding factors due to differences in individual, household, and job characteristics, we add a number of control variables to our models. These are respondents' age, marital status, children at home, level of education, work experience, changes in employment (e.g. promotions and demotions within the same job as well as job switches), two or more jobs, contract type, level of occupation, number of supervised employees, sector, firm size, and a time trend. Observations with missing values on any of these variables are dropped from the analysis by listwise deletion, resulting in a net sample of 16,022 observations from 7164 individuals. Table 4 shows the descriptive statistics for both this net sample and the gross sample $(N=20,452)$ without listwise deletions.

\section{Empirical analysis}

Our analysis starts out with a simple cross-tabulation of the TLF and working hour variables (Table 5). A comparison of working hours of employees with and without TLF seems

Table 3 Average working hours by gender

\begin{tabular}{|c|c|c|c|c|c|c|c|}
\hline \multirow[t]{2}{*}{ Working hours } & \multicolumn{2}{|l|}{ Male } & \multicolumn{2}{|c|}{ Female } & \multicolumn{2}{|l|}{ Total } & \multirow[t]{2}{*}{$\mathrm{N}$} \\
\hline & Mean & S.E. & Mean & S.E. & Mean & S.E. & \\
\hline Actual hours & 39.66 & $(0.10)$ & 27.05 & (0.13) & 33.63 & $(0.10)$ & 14,046 \\
\hline Contracted hours & 36.58 & $(0.07)$ & 25.24 & $(0.11)$ & 31.12 & $(0.08)$ & 16,022 \\
\hline Preferred hours & 35.85 & $(0.08)$ & 25.29 & $(0.11)$ & 30.76 & $(0.08)$ & 16,022 \\
\hline
\end{tabular}

Note: Employees' average working hours by gender

S.E. standard error of the mean 
Table 4 Descriptive statistics

\begin{tabular}{|c|c|c|c|c|c|c|}
\hline \multirow[b]{2}{*}{ Variables } & \multicolumn{2}{|c|}{ Gross sample } & \multicolumn{2}{|c|}{ Net sample } & \multirow[b]{2}{*}{ Min } & \multirow[b]{2}{*}{ Max } \\
\hline & Mean & S.E. & Mean & S.E. & & \\
\hline Actual hours & 31.32 & $(0.099)$ & 33.63 & $(0.096)$ & 0 & 90 \\
\hline Contracted hours & 30.48 & $(0.077)$ & 31.12 & $(0.078)$ & 0 & 91 \\
\hline Preferred hours & 30.10 & $(0.076)$ & 30.76 & $(0.078)$ & 0 & 91 \\
\hline Flexi-time & 0.38 & $(0.003)$ & 0.39 & $(0.004)$ & 0 & 1 \\
\hline Telehomework & 0.18 & $(0.003)$ & 0.18 & $(0.003)$ & 0 & 1 \\
\hline Age & 41.16 & $(0.085)$ & 42.70 & $(0.088)$ & 16 & 66 \\
\hline \multicolumn{7}{|l|}{ Marital status } \\
\hline Married & 0.63 & $(0.003)$ & 0.68 & $(0.004)$ & 0 & 1 \\
\hline Cohabiting & 0.12 & $(0.002)$ & 0.12 & $(0.003)$ & 0 & 1 \\
\hline Single & 0.25 & $(0.003)$ & 0.20 & $(0.003)$ & 0 & 1 \\
\hline Child(ren) & 0.53 & $(0.003)$ & 0.56 & $(0.004)$ & 0 & 1 \\
\hline \multicolumn{7}{|l|}{ Education } \\
\hline Primary school & 0.03 & $(0.001)$ & 0.02 & $(0.001)$ & 0 & 1 \\
\hline Lower secondary & 0.22 & $(0.003)$ & 0.21 & $(0.003)$ & 0 & 1 \\
\hline Higher secondary & 0.39 & $(0.003)$ & 0.39 & $(0.004)$ & 0 & 1 \\
\hline Vocational college & 0.25 & $(0.003)$ & 0.27 & $(0.003)$ & 0 & 1 \\
\hline Academic & 0.10 & $(0.002)$ & 0.11 & $(0.002)$ & 0 & 1 \\
\hline Work experience & 20.77 & $(0.081)$ & 21.24 & $(0.088)$ & 0 & 52 \\
\hline Permanent contract & 0.82 & $(0.003)$ & 0.87 & $(0.003)$ & 0 & 1 \\
\hline Empl. status change & 0.35 & $(0.003)$ & 0.33 & $(0.004)$ & 0 & 1 \\
\hline Second job & 0.07 & $(0.002)$ & 0.07 & $(0.002)$ & 0 & 1 \\
\hline \multicolumn{7}{|l|}{ Supervised employees } \\
\hline None & 0.70 & $(0.003)$ & 0.69 & $(0.004)$ & 0 & 1 \\
\hline 1-9 employees & 0.20 & $(0.003)$ & 0.22 & $(0.003)$ & 0 & 1 \\
\hline 10-49 employees & 0.08 & $(0.002)$ & 0.08 & $(0.002)$ & 0 & 1 \\
\hline 50 or more employees & 0.02 & $(0.001)$ & 0.02 & $(0.001)$ & 0 & 1 \\
\hline \multicolumn{7}{|l|}{ Occupational level } \\
\hline Elementary & 0.06 & $(0.002)$ & 0.04 & $(0.002)$ & 0 & 1 \\
\hline Lower & 0.25 & $(0.003)$ & 0.21 & $(0.003)$ & 0 & 1 \\
\hline Medium & 0.35 & $(0.003)$ & 0.37 & $(0.004)$ & 0 & 1 \\
\hline Higher & 0.26 & $(0.003)$ & 0.29 & $(0.004)$ & 0 & 1 \\
\hline Scientific & 0.08 & $(0.002)$ & 0.09 & $(0.002)$ & 0 & 1 \\
\hline \multicolumn{7}{|l|}{ Sector } \\
\hline Agriculture & 0.01 & $(0.001)$ & 0.01 & $(0.001)$ & 0 & 1 \\
\hline Industry & 0.11 & $(0.002)$ & 0.12 & $(0.003)$ & 0 & 1 \\
\hline Construction & 0.04 & $(0.001)$ & 0.04 & $(0.002)$ & 0 & 1 \\
\hline Trade, gastronomy, repair & 0.16 & $(0.003)$ & 0.14 & $(0.003)$ & 0 & 1 \\
\hline Transport & 0.06 & $(0.002)$ & 0.06 & $(0.002)$ & 0 & 1 \\
\hline Business services & 0.16 & $(0.003)$ & 0.17 & $(0.003)$ & 0 & 1 \\
\hline Care, welfare & 0.21 & $(0.003)$ & 0.21 & $(0.003)$ & 0 & 1 \\
\hline Other services & 0.05 & $(0.002)$ & 0.05 & $(0.002)$ & 0 & 1 \\
\hline Government & 0.09 & $(0.002)$ & 0.10 & $(0.002)$ & 0 & 1 \\
\hline Education & 0.10 & $(0.002)$ & 0.11 & $(0.002)$ & 0 & 1 \\
\hline No. of employees (/1000) & 0.53 & $(0.016)$ & 0.57 & $(0.018)$ & 0 & 70 \\
\hline 2002 & 0.15 & $(0.002)$ & 0.12 & $(0.003)$ & 0 & 1 \\
\hline 2004 & 0.16 & $(0.003)$ & 0.17 & $(0.003)$ & 0 & 1 \\
\hline 2006 & 0.19 & $(0.003)$ & 0.19 & $(0.003)$ & 0 & 1 \\
\hline 2008 & 0.18 & $(0.003)$ & 0.19 & $(0.003)$ & 0 & 1 \\
\hline 2010 & 0.16 & $(0.003)$ & 0.16 & $(0.003)$ & 0 & 1 \\
\hline 2012 & 0.16 & $(0.003)$ & 0.17 & $(0.003)$ & 0 & 1 \\
\hline Observations & 20,452 & & 16,022 & & & \\
\hline
\end{tabular}

Note: The gross sample comprises the observations of all employees in the sample, the net sample those observations used for estimation after listwise deletion due to missing values

S.E. standard error of the mean 
Table 5 Average working hours by flexi-time and telehomework

\begin{tabular}{|c|c|c|c|c|c|c|c|c|}
\hline \multirow[t]{3}{*}{ Working hours } & \multicolumn{4}{|c|}{ Flexi-time } & \multicolumn{4}{|c|}{ Telehomework } \\
\hline & \multicolumn{2}{|l|}{ Yes } & \multicolumn{2}{|l|}{ No } & \multicolumn{2}{|l|}{ Yes } & \multicolumn{2}{|l|}{ No } \\
\hline & Mean & S.E. & Mean & S.E. & Mean & S.E. & Mean & S.E. \\
\hline Actual hours & 36.26 & $(0.15)$ & 31.86 & $(0.12)$ & 36.98 & $(0.15)$ & 31.86 & $(0.12)$ \\
\hline Contracted hours & 32.93 & $(0.11)$ & 29.94 & $(0.10)$ & 32.98 & $(0.11)$ & 30.17 & $(0.10)$ \\
\hline Preferred hours & 32.32 & $(0.12)$ & 29.75 & $(0.10)$ & 32.30 & $(0.12)$ & 29.98 & $(0.10)$ \\
\hline
\end{tabular}

Note: Employees' average working hours by flexi-time and telehomework

S.E. standard error of the mean

to support the hypothesis that TLF is associated with increased labour supply. Contracted and preferred hours are on average 2 to $3 \mathrm{~h}$ longer for flex-timers and telehomeworkers than for their colleagues without those types of TLF. Actual hours are even $5 \mathrm{~h}$ longer for employees with TLF.

Not surprisingly, this finding is supported by simple correlations between the TLF and working hour variables (Table 6). All correlation coefficients are positive and significantly different from zero, except for the male sample, where the correlations between telehomework and contracted and preferred hours, respectively, are not significant. The correlation coefficients on actual hours are always larger than those on contracted and preferred hours and the coefficients on flexi-time are larger than those on telehomework (with one exception, namely actual hours of female employees). So based on simple descriptives, the notion that TLF is associated with a longer work duration appears to be supported by the data.

These simple correlations do not take any confounding factors like individual and job characteristics into account of course. These are likely to play an important role, however. Availability and usage of TLF arrangements as well as working hours differ across jobs, organisations, and industries (see Table 2 for example) as a result of structural differences in production processes and institutional settings. Telehomework for instance is hard to implement in assembly line jobs, while it is a common feature of consultancy jobs nowadays. Furthermore, the degree of availability depends on employers' cost and benefit differentials in the implementation and support of flexibility arrangements. Supervision and monitoring costs differ between jobs and tasks but are likely to be larger if employees are not predictably available at the workplace for example. Firm characteristics may also play a role. In small establishments for example, each member of a team is often seen as critical to business operations, which is why managers may be more reluctant to allow

Table 6 Pairwise correlations of variables

\begin{tabular}{lllll}
\hline & Actual hours & Contracted hours & Preferred hours & Flexi-time \\
\hline $\begin{array}{l}\text { Total }(N=16022) \\
\text { Flexi-time }\end{array}$ & $0.189^{* *}$ & $0.147^{* *}$ & $0.127^{* *}$ & 1.000 \\
$\begin{array}{l}\text { Telehomework } \\
\text { Male }(N=8299)\end{array}$ & $0.151^{* *}$ & $0.061^{* *}$ & $0.049^{* *}$ & $0.196^{* *}$ \\
Flexi-time & & & & \\
Telehomework & $0.171^{* *}$ & $0.082^{* *}$ & $0.060^{* *}$ & 1.000 \\
Female $(N=7723)$ & $0.161^{* *}$ & 0.012 & -0.002 & $0.221^{* *}$ \\
Flexi-time & & & & 1.000 \\
Telehomework & $0.127^{* *}$ & $0.113^{* *}$ & $0.089^{* *}$ & $0.162^{* *}$ \\
\hline${ }_{*}^{* *} p<0.01$ & $0.171^{* *}$ & $0.091^{* *}$ & $0.079^{* *}$ &
\end{tabular}


their employees to work at home. Availability and usage of TLF as well as work length are therefore to a certain extent determined by and dependent on job characteristics, some of which may not be directly observable. It is therefore necessary to control for job-related heterogeneity in the analysis.

Individual employee characteristics are also likely to influence both the availability and utilisation of TLF arrangements. Preferences for working hours and TLF depend both on changes in individual and household characteristics (marital status, children, etc.), as well as on the more general intrinsic preferences for work and leisure. These preferences also influence job choice. Since the availability of TLF arrangements differs between jobs and organisations, employees with stronger preferences for TLF may sort into firms and jobs that are more likely to provide TLF arrangements. In addition, employees with preferences for fewer work hours, e.g. due to private responsibilities, may sort into jobs with more TLF as well, because they give them more room to combine work and private life.

As a next step in the analysis, we therefore control for individual and job-related heterogeneity without putting too much structure on the data. We regress the three working hours variables as well as the two indicators for TLF, flexi-time, and telehomework, on the same set of control variables (see Section 3) and calculate correlations between the residuals from these regressions. This will essentially give us correlation coefficients between TLF and working hours after controlling for a number of confounding factors. The regression models are given by the following equation:

$$
F_{i t}=\gamma^{\prime} Z_{i t}+\delta_{t}+\alpha_{i}+\epsilon_{i t}
$$

$F_{i t}$ designates the different outcome variables (flexi-time and telehomework as well as actual, contracted, and preferred hours, respectively) ${ }^{10}$, and $Z_{i t}$ a vector of control variables. $\delta_{t}$ represents time effects, $\alpha_{i}$ is the individual-specific, and $\epsilon_{i t}$ the idiosyncratic error term. $i$ denominates the individual and $t$ the wave ( $\Delta t$ is 2 years in this biennial panel). $\gamma$ is a vector of parameters to be estimated.

We estimate Eq. 3 with a fixed-effects specification to control for individual-specific effects. This rules out that individual preferences influence the use of TLF and the number of working hours at the same time for example. It also controls for time-invariant job-related heterogeneity. ${ }^{11}$ Furthermore, we estimate the model for the total sample and separately for male and female employees, because male and female employees usually have different non-work responsibilities and react differently to labour market incentives (e.g. Blau and Kahn 2007). ${ }^{12}$ Standard errors are clustered at the level of individual employee. After estimating these models, we calculate the residuals from the regressions (i.e. the term $\epsilon_{i t}$ in Eq. 3) and the correlations between these.

Table 7 shows the pairwise correlations between the residuals. In general, these correlations are small (i.e. $\leq 0.06$ and five correlations loose statistical significance) and much smaller than the unconditional ones (down to a third or less). For the total sample, there is no significant correlation between flexi-time and contracted or preferred hours, and a small correlation (0.017) between flexi-time and actual hours. For male employees, the correlation between flexi-time and actual hours remains positive but is less than a fourth of the original correlation $(0.039$ vs. 0.171$)$. For the female sample, the correlations between flexi-time and contracted or preferred hours even turn out to be negative. The correlations between telehomework and actual hours are positive and significantly 
Table 7 Pairwise correlations of residuals after fixed-effects estimation

\begin{tabular}{lllll}
\hline & Actual hours & Contracted hours & Preferred hours & Flexi-time \\
\hline $\begin{array}{llll}\text { Total }(N=16022) \\
\text { Flexi-time }\end{array}$ & $0.017^{*}$ & -0.007 & -0.003 & 1.000 \\
$\begin{array}{l}\text { Telehomework } \\
\text { Male }(N=8299)\end{array}$ & $0.053^{* *}$ & $0.020^{*}$ & $0.020^{*}$ & $0.043^{* *}$ \\
Flexi-time & $0.039^{* *}$ & 0.014 & & \\
Telehomework & $0.041^{* *}$ & 0.001 & 0.018 & 1.000 \\
Female $(N=7723)$ & & & 0.011 & $0.040^{* *}$ \\
Flexi-time & -0.008 & $-0.027^{*}$ & $-0.029^{*}$ & 1.000 \\
Telehomework & $0.060^{* *}$ & $0.029^{* *}$ & $0.024^{*}$ & $0.044^{* *}$ \\
\hline
\end{tabular}

Note: See Tables 11 and 12 in the Appendix for regressors used and parameter estimates ${ }^{*} p<0.05,{ }^{* *} p<0.01$

different from zero for all samples. For contracted and preferred hours, the correlations with telehomework are statistically insignificant for the male sample.

These results imply that much of the raw correlation between working hours and TLF arrangements is due to individual and job-related heterogeneity. After controlling for this heterogeneity, the correlations between flexi-time and work hours are ambiguous, and the correlations between telehomework and work hours are generally small and positive. Ideally though, we would also like to quantify the relative effects of both TLF arrangements on working hours. We therefore estimate a simple model in which working hours depend on whether employees have flexible working times or can work at home. This model allows us to estimate the relative effects of both TLF arrangements at the same time. It also allows us to easily estimate the effects for different sub-samples. The model looks as follows:

$$
H_{i t}=\beta_{1} f t_{i t}+\beta_{2} t w_{i t}+\kappa^{\prime} Z_{i t}+\delta_{t}+\omega_{i}+\eta_{i t}
$$

$H_{i t}$ designates three different measures of working hours (actual, contracted, and preferred hours, respectively), $f t$ flexi-time, $t w$ telehomework, and $Z$ a vector of control variables. $\delta_{t}$ represents time effects, $\omega_{i}$ is the individual-specific, and $\eta_{i t}$ the idiosyncratic error term. $\beta$ and $\kappa$ are (vectors of) parameters to be estimated. Again we estimate the model with a fixed-effects specification for the total, male, and female samples. ${ }^{13}$ Standard errors are clustered at the level of the individual employee. The data would support the hypothesis if the beta coefficients are positive and significantly different from zero.

Table 8 presents the parameter estimates of flexi-time and telehomework on working hours per week. According to our estimations, the flexi-time coefficients are statistically insignificant except for males with respect to actual hours (0.555). This would imply an increase in actual hours of $33 \mathrm{~min}$ per week (i.e. $0.555 \mathrm{~h} /$ week * $60 \mathrm{~min} / \mathrm{h}$ ).

The coefficients on telehomework are positive, but only significantly different from zero with respect to actual hours for all samples and for female employees with respect to contracted hours. The estimates indicate an increase in actual hours of around $55 \mathrm{~min}$ in actual working hours per week for the total sample. This would translate into an increase of $2.7 \%$ in actual hours (50 min relative to 33.63 mean actual hours in the sample). For female employees, the coefficient suggests an increase of $66 \mathrm{~min} /$ week. For the male sub-sample, the coefficient indicates an increase of some $41 \mathrm{~min} /$ week. These findings 
Table 8 TLF arrangements on working hours

\begin{tabular}{|c|c|c|c|c|c|c|c|c|c|}
\hline & \multicolumn{3}{|c|}{ Actual hours } & \multicolumn{3}{|c|}{ Contracted hours } & \multicolumn{3}{|c|}{ Preferred hours } \\
\hline & Total & Male & Female & Total & Male & Female & Total & Male & Female \\
\hline \multirow[t]{2}{*}{ Flexi-time } & 0.223 & $0.555^{*}$ & -0.189 & -0.094 & 0.151 & -0.396 & -0.055 & 0.269 & -0.484 \\
\hline & $(0.208)$ & $(0.278)$ & $(0.307)$ & $(0.153)$ & $(0.183)$ & $(0.247)$ & $(0.186)$ & $(0.255)$ & $(0.266)$ \\
\hline \multirow[t]{2}{*}{ Telehomework } & $0.920^{* *}$ & $0.681^{*}$ & $1.103^{* *}$ & 0.291 & 0.010 & $0.501^{*}$ & 0.366 & 0.183 & 0.474 \\
\hline & $(0.218)$ & $(0.298)$ & $(0.312)$ & $(0.150)$ & $(0.182)$ & $(0.241)$ & (0.199) & $(0.275)$ & $(0.281)$ \\
\hline Observations & 14,046 & 7325 & 6721 & 16,022 & 8299 & 7723 & 16,022 & 8299 & 7723 \\
\hline Individuals & 6409 & 3333 & 3076 & 7164 & 3681 & 3483 & 7164 & 3681 & 3483 \\
\hline
\end{tabular}

generally fit in with previous research, which found a positive association between telehomework and overtime (Noonan and Glass 2012; Peters and van der Lippe 2007; Peters et al. 2009).

In general, the estimates from Eq. 4 are in line with the results obtained from the correlation of residuals. Our results are therefore not sensitive to either specification, and both estimation strategies show that the association between TLF arrangements and hours worked is generally small.

\section{Sensitivity analyses}

These baseline estimates imply no significant association between TLF and working hours except for a positive association between flexi-time and actual hours for males as well as telehomework and actual hours for both males and females. There is also a positive association between telehomework and contracted hours for females. All of the associations are roughly in the range of half an hour to $1 \mathrm{~h}$ of working time per week.

Until now we did not include wage per hour in our specifications, even though wage is a potentially important factor in the relationship between TLF and working hours, because employees may trade wage instead of leisure for more flexibility (see Eqs. 1 and 2). The classic interpretation in labour economics is that more flexibility and control for employees implies compensating wage differentials, assuming that it provides utility to employees but costs to employers (Altonji and Paxson 1988; Baughman et al. 2003; Heywood et al. 2007. TLF may, however, also provide (net) benefits to employers, e.g. through higher employee productivity (e.g. Bloom et al. 2015), effort, and (employer-oriented) flexibility, or lower turnover, costs for office space, and absenteeism (Possenriede et al. 2014). Most previous empirical analyses regarding the TLF-wage relationship indeed seem to suggest that the net effect of TLF on wages is either absent or positive (e.g. Anderson et al. 2003; Bonke et al. 2004; Gariety and Shaffer 2001; Johnson and Provan 1995; Lowen and Sicilian 2009).

Due to the so-called division bias (Borjas 1980), we cannot just add wage as an independent variable to Eq. $4 .{ }^{14}$ We therefore instrument wage with lagged wage from the previous wave and add this to Eq. $4 .{ }^{15}$ This leads to a significant drop in sample size but gives similar results compared to the baseline specifications nevertheless (see Table 9, panel 1). The coefficients are even virtually the same when we compare the specification with wage included with the baseline specification with wage excluded both estimated on the same reduced sample (not shown). This means that the inclusion of wage does not affect the association (or lack thereof) between TLF and working hours. ${ }^{16}$ 
Table 9 TLF arrangements on working hours-robustness checks

\begin{tabular}{|c|c|c|c|c|c|c|c|c|c|}
\hline & \multicolumn{3}{|c|}{ Actual hours } & \multicolumn{3}{|c|}{ Contracted hours } & \multicolumn{3}{|c|}{ Preferred hours } \\
\hline & Total & Male & Female & Total & Male & Female & Total & Male & Female \\
\hline \multicolumn{10}{|c|}{ Instrumented wage included } \\
\hline \multirow[t]{2}{*}{ Flexi-time } & $0.603^{*}$ & $1.104^{* *}$ & 0.078 & 0.259 & $0.422^{*}$ & 0.077 & 0.236 & 0.390 & -0.091 \\
\hline & $(0.240)$ & $(0.327)$ & $(0.351)$ & $(0.162)$ & $(0.179)$ & $(0.281)$ & $(0.228)$ & $(0.333)$ & $(0.294)$ \\
\hline \multirow[t]{2}{*}{ Telehomework } & $0.853^{* *}$ & $0.769^{*}$ & $0.866^{*}$ & 0.244 & 0.075 & 0.397 & 0.224 & 0.085 & 0.413 \\
\hline & $(0.245)$ & $(0.309)$ & $(0.389)$ & $(0.165)$ & $(0.182)$ & $(0.298)$ & $(0.220)$ & $(0.314)$ & $(0.305)$ \\
\hline Observations & 6771 & 3581 & 3190 & 6779 & 3583 & 3196 & 6779 & 3583 & 3196 \\
\hline Individuals & 2245 & 1174 & 1071 & 2246 & 1174 & 1072 & 2246 & 1174 & 1072 \\
\hline \multicolumn{10}{|c|}{ Lagged values flexi-time and telehomework as IV } \\
\hline \multirow[t]{2}{*}{ Flexi-time } & -0.963 & -0.543 & -1.326 & -0.169 & -1.211 & -0.006 & -0.756 & -2.334 & 0.080 \\
\hline & $(1.682)$ & $(2.143)$ & $(2.859)$ & $(1.338)$ & $(1.559)$ & $(2.473)$ & $(1.807)$ & $(2.419)$ & (3.073) \\
\hline \multirow[t]{2}{*}{ Telehomework } & -0.758 & 1.440 & -0.698 & -1.894 & -2.173 & -0.518 & -1.704 & -1.952 & -0.619 \\
\hline & $(1.944)$ & $(3.112)$ & $(2.380)$ & $(1.289)$ & $(2.126)$ & $(1.536)$ & $(1.668)$ & $(3.116)$ & $(1.813)$ \\
\hline Observations & 7696 & 4059 & 3637 & 7706 & 4062 & 3644 & 7706 & 4062 & 3644 \\
\hline Individuals & 2517 & 1309 & 1208 & 2518 & 1309 & 1209 & 2518 & 1309 & 1209 \\
\hline \multicolumn{10}{|c|}{ Lagged values flexi-time and telehomework } \\
\hline \multirow[t]{2}{*}{ Flexi-time $e_{\mathrm{t}-1}$} & 0.095 & 0.136 & 0.139 & -0.028 & 0.059 & -0.001 & 0.047 & 0.216 & -0.011 \\
\hline & $(0.192)$ & $(0.236)$ & $(0.305)$ & $(0.152)$ & $(0.167)$ & $(0.265)$ & $(0.212)$ & $(0.274)$ & $(0.330)$ \\
\hline \multirow[t]{2}{*}{ Telehomework $\mathrm{t}-1_{\mathrm{H}}$} & 0.086 & -0.162 & 0.103 & 0.249 & 0.208 & 0.087 & 0.214 & 0.165 & 0.106 \\
\hline & $(0.250)$ & $(0.312)$ & $(0.399)$ & $(0.165)$ & $(0.208)$ & $(0.262)$ & $(0.219)$ & $(0.307)$ & $(0.317)$ \\
\hline Observations & 9370 & 4927 & 4443 & 9385 & 4933 & 4452 & 9385 & 4933 & 4452 \\
\hline Individuals & 4191 & 2177 & 2014 & 4197 & 2180 & 2017 & 4197 & 2180 & 2017 \\
\hline \multicolumn{10}{|c|}{ Winsored working hours } \\
\hline \multirow[t]{2}{*}{ Flexi-time } & 0.184 & 0.464 & -0.162 & -0.126 & 0.087 & -0.383 & -0.088 & 0.182 & -0.440 \\
\hline & $(0.201)$ & $(0.263)$ & $(0.303)$ & $(0.150)$ & $(0.176)$ & $(0.246)$ & $(0.176)$ & $(0.237)$ & $(0.258)$ \\
\hline
\end{tabular}


Table 9 TLF arrangements on working hours-robustness checks (Continuation)

\begin{tabular}{|c|c|c|c|c|c|c|c|c|c|}
\hline \multirow[t]{2}{*}{ Telehomework } & $0.944^{* *}$ & $0.723^{*}$ & $1.098^{* *}$ & 0.271 & -0.024 & $0.495^{*}$ & 0.302 & 0.121 & 0.403 \\
\hline & $(0.216)$ & $(0.293)$ & $(0.311)$ & $(0.146)$ & $(0.174)$ & $(0.238)$ & $(0.186)$ & $(0.258)$ & $(0.261)$ \\
\hline Observations & 14046 & 7325 & 6721 & 16022 & 8299 & 7723 & 16022 & 8299 & 7723 \\
\hline Individuals & 6409 & 3333 & 3076 & 7164 & 3681 & 3483 & 7164 & 3681 & 3483 \\
\hline \multicolumn{10}{|l|}{ 2004-2012 only } \\
\hline \multirow[t]{2}{*}{ Flexi-time } & 0.223 & $0.555^{*}$ & -0.189 & -0.008 & 0.192 & -0.256 & 0.041 & 0.284 & -0.312 \\
\hline & $(0.208)$ & $(0.278)$ & $(0.307)$ & $(0.168)$ & $(0.202)$ & $(0.270)$ & $(0.200)$ & $(0.273)$ & $(0.284)$ \\
\hline \multirow[t]{2}{*}{ Telehomework } & $0.920^{* *}$ & $0.681^{*}$ & $1.103^{* *}$ & 0.199 & -0.089 & 0.438 & 0.215 & -0.141 & $0.573^{*}$ \\
\hline & $(0.218)$ & $(0.298)$ & $(0.312)$ & $(0.155)$ & $(0.192)$ & $(0.248)$ & $(0.202)$ & $(0.274)$ & $(0.292)$ \\
\hline Observations & 14046 & 7325 & 6721 & 14046 & 7325 & 6721 & 14046 & 7325 & 6721 \\
\hline Individuals & 6409 & 3333 & 3076 & 6409 & 3333 & 3076 & 6409 & 3333 & 3076 \\
\hline
\end{tabular}

Note: Parameter estimates of TLF arrangements on working hours. Standard errors in parentheses (clustered at employee level)

${ }^{*} p<0.05,{ }^{* *} p<0.01$ 
More generally, our estimates do not allow for drawing strong conclusions about the causal effect of flexi-time and telehomework on labour supply, however. This is due to the following issues. Self-selection and other sources of endogeneity, like common shocks that may at the same time influence the availability and usage of TLF on the one hand and the number of working hours on the other, may bias our estimates. Many employees may for example choose working hours and working conditions simultaneously as parts of a whole employment package at the start of a contract. ${ }^{17}$ Time-varying family commitments like elderly care or the birth of a (second) child may lead to both decreases in hours worked and higher demand for TLF. Employers may also award TLF to employees with the largest productivity, status, or authority (cf. Golden 2009; Winder 2009; Noonan and Glass 2012). Since we control for changes in employment as well as for time-fixed-effects, both of these confounding factors are only relevant, however, if they are time-varying and independent of promotions and job switches for example.

Underlying the specification as depicted by Eq. 4 is furthermore that the idiosyncratic error term $\epsilon_{i t}$ is strictly exogenous, i.e. that time-varying unobserved variables from any time period may not be correlated with any of the explanatory variables from all time periods. This assumption would be violated for example, if there were reverse causality or a feedback mechanism going on. This might be the case for TLF, because instead of being a policy for improved working conditions and work-life fit, employees might get more TLF, when (actual) working hours and workloads increase in order to get the job done (Noonan and Glass 2012). This means that causality would run from increased hours to TLF and not the other way around. Prior research has indeed shown that employees at the high end of the hour spectrum have considerably more access to flexi-time for example than those with a standard 40-h working week. Part-time employees, however, enjoy greater availability than full-time employees as well, so access to TLF seems to actually be Ushaped in working hours (Golden 2008; 2009). So there might be a feedback mechanism that may work in both directions, which means that the overall impact on our estimates is unclear.

We have considered the following procedures to remedy these potential issues. First, we took alternative estimation techniques like differences in differences or regression discontinuity into account. Unfortunately, these cannot be applied, because there is no exogenous variation in the availability of schedule and location flexibility during the period under consideration and there is no exogenous variation in the dependent variables either. The closest is the Working Hours Adjustment Act, which was implemented in 2000. Important variables for our analysis, among them the number of actual work hours and availability of telehomework, are not available in the AAP before 2004 and 2002, respectively, however.

Next, we tried to find suitable external instrumental variables for TLF. We tested various autonomy measures as IVs for telehomework and flexi-time such as "I can determine how I do my job", "I can determine my work speed", or "I can determine in which order I do my work", for instance. All of these variables turned out to be weak instruments in the fixedeffects specification, however, and would therefore lead to inconsistent estimates. Hence, we were not able to find any suitable external instrumental variables in our data.

We were able to use flexi-time and telehomework from the previous wave as internal instruments. This again leads to a significant drop in sample size, because only those 
respondents with observations from at least two subsequent waves can be used. All coefficients indicate no significant association between TLF and working hours (see Table 9, panel 2).

Next we experimented with the inclusion of lags of flexi-time and telehomework to take possible adjustment lags into account. Again, the results indicate a significant drop in sample size and no significant association between TLF and working hours (panel 3).

We also winsorised the working hour variables to the 1st and 99th percentile, limiting the range to 3 to $60 \mathrm{~h}$ per week, to rule out that outliers may be driving our results. In addition, we excluded the 2002 wave from our sample, since the answer categories for the frequency of telehomework, on which our telehomework variable ultimately relies, differ in this wave, and to rule out that the differences in effects with respect to actual, contracted, and preferred is merely caused by differences in data availability. Most coefficients in these two specifications are statistically insignificant, and where they are significant, the results are comparable to the baseline estimates (panels 4 and 5). ${ }^{18}$

As a next step, we also estimated Eq. 4 with various interactions (see Table 10). First, we estimated the model with an interaction between flexi-time and telework. This interaction is statistically insignificant in all of the specifications tested, which means that schedule and location flexibility are independent types of flexibility (panel 1). Second, we respectively interacted flexi-time and telehomework with whether or not there are children at home or whether the individual is below or above the median age of 42 years. One may assume that these groups differ in their preferences for TLF and their propensity to adjust working hours (panels 2 and 3). Third, we created indicator variables for white-collar workers (i.e. employees with a "higher" or "scientific" level of occupation) and service sector jobs (i.e. those in business services, other services, government and education sectors, as opposed to agriculture, industry, construction, trade, gastronomy, repair, transport, care, and welfare). For both these groups, we may assume that they have better access to TLF and can more easily adjust working hours. We interact both variables with flexi-time and telehomework, respectively (panels 4 and 5). Finally, we added an interaction between flexi-time and telehomework and whether or not the wave is post 2008 to account for possible effects due to the Great Recession.

While the occasional coefficient of these interactions may be significantly different from zero, the bigger picture is that the above-mentioned interactions are generally not significant and that the main effects are quite similar to the baseline specification. This means that according to our estimates there seem to be little to no differences in the associations between TLF and the supply of working hours for different groups of employees.

\section{Conclusions}

In this paper, we analyse the effect of temporal and locational flexibility of work (TLF) on the number of working hours using Dutch household panel data spanning the period from 2002 to 2012. We test the claim that more TLF is associated with an increase in labour supply due to a better fit between work and private life. An increase of TLF has been a common policy recommendation to boost labour supply in order to enhance economic growth and to prevent labour force shortages in the future.

According to our estimates, the general association between TLF and the number of working hours is small at best. According to our baseline results, telehomework is 
Table 10 TLF arrangements on working hours_robustness checks: interaction

\begin{tabular}{|c|c|c|c|c|c|c|c|c|c|}
\hline & \multicolumn{3}{|c|}{ Actual hours } & \multicolumn{3}{|c|}{ Contracted hours } & \multicolumn{3}{|c|}{ Preferred hours } \\
\hline & Total & Male & Female & Total & Male & Female & Total & Male & Female \\
\hline \multicolumn{10}{|c|}{ Interaction between flexi-time and telehomework } \\
\hline Flexi-time & $\begin{array}{l}0.189 \\
(0.222)\end{array}$ & $\begin{array}{l}0.547 \\
(0.298)\end{array}$ & $\begin{array}{l}-0.262 \\
(0.329)\end{array}$ & $\begin{array}{l}-0.053 \\
(0.166)\end{array}$ & $\begin{array}{l}0.205 \\
(0.198)\end{array}$ & $\begin{array}{l}-0.374 \\
(0.271)\end{array}$ & $\begin{array}{l}-0.017 \\
(0.197)\end{array}$ & $\begin{array}{l}0.348 \\
(0.272)\end{array}$ & $\begin{array}{l}-0.493 \\
(0.282)\end{array}$ \\
\hline Telehomework & $\begin{array}{l}0.817^{*} \\
(0.340)\end{array}$ & $\begin{array}{l}0.653 \\
(0.480)\end{array}$ & $\begin{array}{l}0.922 \\
(0.476)\end{array}$ & $\begin{array}{l}0.408 \\
(0.222)\end{array}$ & $\begin{array}{l}0.193 \\
(0.287)\end{array}$ & $\begin{array}{l}0.552 \\
(0.329)\end{array}$ & $\begin{array}{l}0.475 \\
(0.291)\end{array}$ & $\begin{array}{l}0.450 \\
(0.439)\end{array}$ & $\begin{array}{l}0.453 \\
(0.380)\end{array}$ \\
\hline Flexi-time $\times$ telehomework & $\begin{array}{l}0.169 \\
(0.399)\end{array}$ & $\begin{array}{l}0.042 \\
(0.541)\end{array}$ & $\begin{array}{l}0.345 \\
(0.574)\end{array}$ & $\begin{array}{l}-0.201 \\
(0.253)\end{array}$ & $\begin{array}{l}-0.281 \\
(0.313)\end{array}$ & $\begin{array}{l}-0.104 \\
(0.400)\end{array}$ & $\begin{array}{l}-0.188 \\
(0.336)\end{array}$ & $\begin{array}{l}-0.411 \\
(0.493)\end{array}$ & $\begin{array}{l}0.043 \\
(0.461)\end{array}$ \\
\hline \multicolumn{10}{|c|}{ Interaction between flexi-time, telehomework, and median age } \\
\hline Flexi-time & $\begin{array}{l}0.213 \\
(0.337)\end{array}$ & $\begin{array}{l}0.796 \\
(0.435)\end{array}$ & $\begin{array}{l}-0.371 \\
(0.504)\end{array}$ & $\begin{array}{l}-0.192 \\
(0.247)\end{array}$ & $\begin{array}{l}0.239 \\
(0.279)\end{array}$ & $\begin{array}{l}-0.668 \\
(0.406)\end{array}$ & $\begin{array}{l}-0.152 \\
(0.285)\end{array}$ & $\begin{array}{l}0.231 \\
(0.376)\end{array}$ & $\begin{array}{l}-0.604 \\
(0.415)\end{array}$ \\
\hline Telehomework & $\begin{array}{l}1.198^{* *} \\
(0.368)\end{array}$ & $\begin{array}{l}0.584 \\
(0.512)\end{array}$ & $\begin{array}{l}1.569^{* *} \\
(0.510)\end{array}$ & $\begin{array}{l}0.347 \\
(0.245)\end{array}$ & $\begin{array}{l}-0.055 \\
(0.297)\end{array}$ & $\begin{array}{l}0.491 \\
(0.392)\end{array}$ & $\begin{array}{l}0.422 \\
(0.310)\end{array}$ & $\begin{array}{l}0.300 \\
(0.411)\end{array}$ & $\begin{array}{l}0.283 \\
(0.445)\end{array}$ \\
\hline$>$ Median age & $\begin{array}{l}0.644^{*} \\
(0.288)\end{array}$ & $\begin{array}{l}0.225 \\
(0.403)\end{array}$ & $\begin{array}{l}1.092^{* *} \\
(0.390)\end{array}$ & $\begin{array}{l}1.043^{* *} \\
(0.226)\end{array}$ & $\begin{array}{l}0.546 \\
(0.278)\end{array}$ & $\begin{array}{l}1.496^{* *} \\
(0.342)\end{array}$ & $\begin{array}{l}0.928^{* *} \\
(0.265)\end{array}$ & $\begin{array}{l}0.335 \\
(0.355)\end{array}$ & $\begin{array}{l}1.541^{* *} \\
(0.376)\end{array}$ \\
\hline Flexi-time $x>$ median age & $\begin{array}{l}0.009 \\
(0.363)\end{array}$ & $\begin{array}{l}-0.376 \\
(0.484)\end{array}$ & $\begin{array}{l}0.313 \\
(0.532)\end{array}$ & $\begin{array}{l}0.171 \\
(0.266)\end{array}$ & $\begin{array}{l}-0.143 \\
(0.300)\end{array}$ & $\begin{array}{l}0.498 \\
(0.446)\end{array}$ & $\begin{array}{l}0.168 \\
(0.320)\end{array}$ & $\begin{array}{l}0.058 \\
(0.420)\end{array}$ & $\begin{array}{l}0.223 \\
(0.473)\end{array}$ \\
\hline Telehomework $x>$ med age & $\begin{array}{l}-0.447 \\
(0.420)\end{array}$ & $\begin{array}{l}0.138 \\
(0.579)\end{array}$ & $\begin{array}{l}-0.829 \\
(0.580)\end{array}$ & $\begin{array}{l}-0.111 \\
(0.271)\end{array}$ & $\begin{array}{l}0.100 \\
(0.319)\end{array}$ & $\begin{array}{l}-0.096 \\
(0.443)\end{array}$ & $\begin{array}{l}-0.109 \\
(0.356)\end{array}$ & $\begin{array}{l}-0.175 \\
(0.455)\end{array}$ & $\begin{array}{l}0.218 \\
(0.546)\end{array}$ \\
\hline \multicolumn{10}{|c|}{ Interaction between flexi-time, telehomework, and child(ren) at home } \\
\hline Flexi-time & $\begin{array}{l}0.141 \\
(0.330)\end{array}$ & $\begin{array}{l}0.668 \\
(0.448)\end{array}$ & $\begin{array}{l}-0.299 \\
(0.478)\end{array}$ & $\begin{array}{l}0.025 \\
(0.247)\end{array}$ & $\begin{array}{l}0.484 \\
(0.314)\end{array}$ & $\begin{array}{l}-0.263 \\
(0.386)\end{array}$ & $\begin{array}{l}-0.185 \\
(0.308)\end{array}$ & $\begin{array}{l}0.321 \\
(0.446)\end{array}$ & $\begin{array}{l}-0.661 \\
(0.416)\end{array}$ \\
\hline Telehomework & $\begin{array}{l}0.500 \\
(0.384)\end{array}$ & $\begin{array}{l}0.326 \\
(0.539)\end{array}$ & $\begin{array}{l}0.505 \\
(0.540)\end{array}$ & $\begin{array}{l}-0.061 \\
(0.257)\end{array}$ & $\begin{array}{l}-0.272 \\
(0.347)\end{array}$ & $\begin{array}{l}-0.063 \\
(0.376)\end{array}$ & $\begin{array}{l}0.094 \\
(0.300)\end{array}$ & $\begin{array}{l}0.107 \\
(0.429)\end{array}$ & $\begin{array}{l}-0.078 \\
(0.419)\end{array}$ \\
\hline Child(ren) & $\begin{array}{l}-1.292^{* *} \\
(0.308)\end{array}$ & $\begin{array}{l}0.036 \\
(0.398)\end{array}$ & $\begin{array}{l}-2.519^{* *} \\
(0.464)\end{array}$ & $\begin{array}{l}-0.927^{* *} \\
(0.263)\end{array}$ & $\begin{array}{l}0.563 \\
(0.319)\end{array}$ & $\begin{array}{l}-2.300^{* *} \\
(0.394)\end{array}$ & $\begin{array}{l}-0.880^{* *} \\
(0.295)\end{array}$ & $\begin{array}{l}0.301 \\
(0.421)\end{array}$ & $\begin{array}{l}-1.988^{* *} \\
(0.398)\end{array}$ \\
\hline Flexi-time $\times$ child(ren) & $\begin{array}{l}0.142 \\
(0.365)\end{array}$ & $\begin{array}{l}-0.176 \\
(0.492)\end{array}$ & $\begin{array}{l}0.171 \\
(0.532)\end{array}$ & $\begin{array}{l}-0.190 \\
(0.279)\end{array}$ & $\begin{array}{l}-0.541 \\
(0.358)\end{array}$ & $\begin{array}{l}-0.222 \\
(0.423)\end{array}$ & $\begin{array}{l}0.217 \\
(0.333)\end{array}$ & $\begin{array}{l}-0.084 \\
(0.478)\end{array}$ & $\begin{array}{l}0.282 \\
(0.458)\end{array}$ \\
\hline Telehomework $\times$ child(ren) & $\begin{array}{l}0.666 \\
(0.415)\end{array}$ & $\begin{array}{l}0.536 \\
(0.589)\end{array}$ & $\begin{array}{l}0.992 \\
(0.583)\end{array}$ & $\begin{array}{l}0.554 \\
(0.292)\end{array}$ & $\begin{array}{l}0.417 \\
(0.383)\end{array}$ & $\begin{array}{l}0.927^{*} \\
(0.443)\end{array}$ & $\begin{array}{l}0.430 \\
(0.359)\end{array}$ & $\begin{array}{l}0.114 \\
(0.509)\end{array}$ & $\begin{array}{l}0.904 \\
(0.504)\end{array}$ \\
\hline \multicolumn{10}{|c|}{ Interaction between flexi-time, telehomework, and white collar worker } \\
\hline Flexi-time & $\begin{array}{l}0.247 \\
(0.248)\end{array}$ & $\begin{array}{l}0.387 \\
(0.347)\end{array}$ & $\begin{array}{l}0.043 \\
(0.343)\end{array}$ & $\begin{array}{l}-0.019 \\
(0.190)\end{array}$ & $\begin{array}{l}0.150 \\
(0.241)\end{array}$ & $\begin{array}{l}-0.225 \\
(0.292)\end{array}$ & $\begin{array}{l}0.166 \\
(0.226)\end{array}$ & $\begin{array}{l}0.341 \\
(0.331)\end{array}$ & $\begin{array}{l}-0.079 \\
(0.302)\end{array}$ \\
\hline
\end{tabular}


Table 10 TLF arrangements on working hours-robustness checks: interaction (Continuation)

\begin{tabular}{|c|c|c|c|c|c|c|c|c|c|}
\hline Telehomework & $\begin{array}{l}0.794^{*} \\
(0.318)\end{array}$ & $\begin{array}{l}0.812 \\
(0.477)\end{array}$ & $\begin{array}{l}0.577 \\
(0.414)\end{array}$ & $\begin{array}{l}0.246 \\
(0.233)\end{array}$ & $\begin{array}{l}0.059 \\
(0.312)\end{array}$ & $\begin{array}{l}0.314 \\
(0.358)\end{array}$ & $\begin{array}{l}0.365 \\
(0.300)\end{array}$ & $\begin{array}{l}0.636 \\
(0.437)\end{array}$ & $\begin{array}{l}-0.143 \\
(0.402)\end{array}$ \\
\hline White collar & $\begin{array}{l}0.492 \\
(0.279)\end{array}$ & $\begin{array}{l}0.249 \\
(0.379)\end{array}$ & $\begin{array}{l}0.500 \\
(0.405)\end{array}$ & $\begin{array}{l}0.475^{*} \\
(0.223)\end{array}$ & $\begin{array}{l}0.368 \\
(0.282)\end{array}$ & $\begin{array}{l}0.471 \\
(0.335)\end{array}$ & $\begin{array}{l}0.539 \\
(0.276)\end{array}$ & $\begin{array}{l}0.483 \\
(0.386)\end{array}$ & $\begin{array}{l}0.474 \\
(0.388)\end{array}$ \\
\hline Flexi-time $\times$ white collar & $\begin{array}{l}-0.003 \\
(0.320)\end{array}$ & $\begin{array}{l}0.487 \\
(0.418)\end{array}$ & $\begin{array}{l}-0.622 \\
(0.493)\end{array}$ & $\begin{array}{l}-0.125 \\
(0.246)\end{array}$ & $\begin{array}{l}0.102 \\
(0.293)\end{array}$ & $\begin{array}{l}-0.442 \\
(0.409)\end{array}$ & $\begin{array}{l}-0.515 \\
(0.291)\end{array}$ & $\begin{array}{l}-0.127 \\
(0.402)\end{array}$ & $\begin{array}{l}-1.097^{*} \\
(0.428)\end{array}$ \\
\hline Telehomework $\times$ white collar & $\begin{array}{l}0.218 \\
(0.373)\end{array}$ & $\begin{array}{l}-0.222 \\
(0.524)\end{array}$ & $\begin{array}{l}0.949 \\
(0.526)\end{array}$ & $\begin{array}{l}0.078 \\
(0.268)\end{array}$ & $\begin{array}{l}-0.088 \\
(0.335)\end{array}$ & $\begin{array}{l}0.325 \\
(0.433)\end{array}$ & $\begin{array}{l}-0.004 \\
(0.353)\end{array}$ & $\begin{array}{l}-0.736 \\
(0.491)\end{array}$ & $\begin{array}{l}1.020^{*} \\
(0.499)\end{array}$ \\
\hline \multicolumn{10}{|c|}{ Interaction between flexi-time, telehomework, and service-sector jobs } \\
\hline Flexi-time & $\begin{array}{l}0.205 \\
(0.264)\end{array}$ & $\begin{array}{l}0.639 \\
(0.350)\end{array}$ & $\begin{array}{l}-0.399 \\
(0.389)\end{array}$ & $\begin{array}{l}-0.194 \\
(0.195)\end{array}$ & $\begin{array}{l}0.266 \\
(0.241)\end{array}$ & $\begin{array}{l}-0.739^{*} \\
(0.309)\end{array}$ & $\begin{array}{l}-0.071 \\
(0.237)\end{array}$ & $\begin{array}{l}0.403 \\
(0.347)\end{array}$ & $\begin{array}{l}-0.663^{*} \\
(0.312)\end{array}$ \\
\hline Telehomework & $\begin{array}{l}1.094^{* *} \\
(0.307)\end{array}$ & $\begin{array}{l}0.974^{*} \\
(0.441)\end{array}$ & $\begin{array}{l}1.150^{* *} \\
(0.400)\end{array}$ & $\begin{array}{l}0.487^{*} \\
(0.213)\end{array}$ & $\begin{array}{l}0.077 \\
(0.272)\end{array}$ & $\begin{array}{l}0.862^{* *} \\
(0.324)\end{array}$ & $\begin{array}{l}0.520^{*} \\
(0.264)\end{array}$ & $\begin{array}{l}0.331 \\
(0.375)\end{array}$ & $\begin{array}{l}0.668 \\
(0.366)\end{array}$ \\
\hline Services & $\begin{array}{l}0.566 \\
(0.344)\end{array}$ & $\begin{array}{l}0.284 \\
(0.417)\end{array}$ & $\begin{array}{l}0.874 \\
(0.552)\end{array}$ & $\begin{array}{l}0.259 \\
(0.291)\end{array}$ & $\begin{array}{l}0.351 \\
(0.341)\end{array}$ & $\begin{array}{l}0.155 \\
(0.481)\end{array}$ & $\begin{array}{l}0.270 \\
(0.333)\end{array}$ & $\begin{array}{l}0.319 \\
(0.435)\end{array}$ & $\begin{array}{l}0.197 \\
(0.499)\end{array}$ \\
\hline Flexi-time $\times$ services & $\begin{array}{l}0.088 \\
(0.374)\end{array}$ & $\begin{array}{l}-0.190 \\
(0.481)\end{array}$ & $\begin{array}{l}0.563 \\
(0.569)\end{array}$ & $\begin{array}{l}0.218 \\
(0.279)\end{array}$ & $\begin{array}{l}-0.276 \\
(0.339)\end{array}$ & $\begin{array}{l}0.809 \\
(0.448)\end{array}$ & $\begin{array}{l}0.046 \\
(0.341)\end{array}$ & $\begin{array}{l}-0.297 \\
(0.456)\end{array}$ & $\begin{array}{l}0.466 \\
(0.500)\end{array}$ \\
\hline Telehomework $\times$ services & $\begin{array}{l}-0.336 \\
(0.406)\end{array}$ & $\begin{array}{l}-0.572 \\
(0.561)\end{array}$ & $\begin{array}{l}-0.066 \\
(0.570)\end{array}$ & $\begin{array}{l}-0.355 \\
(0.279)\end{array}$ & $\begin{array}{l}-0.179 \\
(0.333)\end{array}$ & $\begin{array}{l}-0.571 \\
(0.463)\end{array}$ & $\begin{array}{l}-0.275 \\
(0.366)\end{array}$ & $\begin{array}{l}-0.289 \\
(0.469)\end{array}$ & $\begin{array}{l}-0.282 \\
(0.577)\end{array}$ \\
\hline \multicolumn{10}{|c|}{ Interaction between flexi-time, telehomework, and post 2008} \\
\hline Flexi-time & $\begin{array}{l}0.346 \\
(0.223)\end{array}$ & $\begin{array}{l}0.656^{*} \\
(0.288)\end{array}$ & $\begin{array}{l}-0.135 \\
(0.335)\end{array}$ & $\begin{array}{l}-0.108 \\
(0.163)\end{array}$ & $\begin{array}{l}0.127 \\
(0.197)\end{array}$ & $\begin{array}{l}-0.444 \\
(0.264)\end{array}$ & $\begin{array}{l}-0.080 \\
(0.192)\end{array}$ & $\begin{array}{l}0.300 \\
(0.256)\end{array}$ & $\begin{array}{l}-0.656^{*} \\
(0.283)\end{array}$ \\
\hline Telehomework & $\begin{array}{l}0.828^{* *} \\
(0.247)\end{array}$ & $\begin{array}{l}-0.583 \\
(0.345)\end{array}$ & $\begin{array}{l}0.974^{* *} \\
(0.346)\end{array}$ & $\begin{array}{l}0.236 \\
(0.169)\end{array}$ & $\begin{array}{l}-0.026 \\
(0.212)\end{array}$ & $\begin{array}{l}0.404 \\
(0.267)\end{array}$ & $\begin{array}{l}0.304 \\
(0.219)\end{array}$ & $\begin{array}{l}0.154 \\
(0.305)\end{array}$ & $\begin{array}{l}0.341 \\
(0.306)\end{array}$ \\
\hline Post 2008 & $\begin{array}{l}-0.056 \\
(0.200)\end{array}$ & $\begin{array}{l}-0.340 \\
(0.279)\end{array}$ & $\begin{array}{l}0.031 \\
(0.284)\end{array}$ & $\begin{array}{l}-0.142 \\
(0.162)\end{array}$ & $\begin{array}{l}-0.167 \\
(0.214)\end{array}$ & $\begin{array}{l}-0.264 \\
(0.240)\end{array}$ & $\begin{array}{l}-0.439^{*} \\
(0.210)\end{array}$ & $\begin{array}{l}-0.644^{*} \\
(0.302)\end{array}$ & $\begin{array}{l}-0.353 \\
(0.294)\end{array}$ \\
\hline Flexi-time $\times$ post 2008 & $\begin{array}{l}-0.338 \\
(0.224)\end{array}$ & $\begin{array}{l}-0.253 \\
(0.293)\end{array}$ & $\begin{array}{l}-0.184 \\
(0.329)\end{array}$ & $\begin{array}{l}0.042 \\
(0.183)\end{array}$ & $\begin{array}{l}0.104 \\
(0.220)\end{array}$ & $\begin{array}{l}0.097 \\
(0.288)\end{array}$ & $\begin{array}{l}0.093 \\
(0.237)\end{array}$ & $\begin{array}{l}-0.074 \\
(0.318)\end{array}$ & $\begin{array}{l}0.468 \\
(0.349)\end{array}$ \\
\hline Telehomework $\times$ post 2008 & $\begin{array}{l}0.267 \\
(0.292)\end{array}$ & $\begin{array}{l}0.264 \\
(0.402)\end{array}$ & $\begin{array}{l}0.366 \\
(0.413)\end{array}$ & $\begin{array}{l}0.150 \\
(0.212)\end{array}$ & $\begin{array}{l}0.092 \\
(0.233)\end{array}$ & $\begin{array}{l}0.262 \\
(0.351)\end{array}$ & $\begin{array}{l}0.109 \\
(0.306)\end{array}$ & $\begin{array}{l}-0.003 \\
(0.411)\end{array}$ & $\begin{array}{l}0.284 \\
(0.441)\end{array}$ \\
\hline Observations & 14046 & 8299 & 6721 & 16022 & 8299 & 7723 & 16022 & 8299 & 7723 \\
\hline Individuals & 6409 & 3681 & 3076 & 7164 & 3681 & 3483 & 7164 & 3681 & 3483 \\
\hline
\end{tabular}

Note: Parameter estimates of TLF arrangements on working hours. Standard errors in parentheses (clustered at employee level)

${ }^{*} p<0.05,{ }^{*} p<0.01$ 
positively associated with actual hours and our results indicate an increase of an hour per week. Contracted and preferred working hours are generally not affected significantly by telehomework, except for a small positive association between telehomework and contracted hours for females. Telehomework therefore does not seem to be associated with a structural increase in contracted nor preferred working hours but seems to be primarily associated with an increase in actual working hours.

At least part of the positive effect of telehomework on actual hours seems to be driven by an increase in unpaid overtime hours. Preliminary estimates indicate that unpaid overtime hours increase by $1.5 \mathrm{~h}$ per week for male employees and $0.75 \mathrm{~h}$ per week for female employees who work at home at least once a week. ${ }^{19}$ This suggests that TLF may also be used for work intensification and an increase in overtime hours, a result that has been discussed before (Noonan and Glass 2012; Peters and van der Lippe 2007). An alternative interpretation is that employees may reciprocate TLF availability by exerting extra effort (Akerlof 1982; Kelliher and Anderson 2010). Previous findings that TLF increases job satisfaction (Possenriede and Plantenga 2014) and job performance (Baltes et al. 1999; Bloom et al. 2015; Eaton 2003; Gajendran and Harrison 2007; Hill et al. 1998) support this interpretation. Both explanations, i.e. telehomework as a means for employers to intensify work on the one hand and more work effort from employees in exchange for more flexibility on the other, may nevertheless apply, particularly at different ends of the job spectrum.

With respect to flexi-time, the results are even more limited. Almost all coefficients are statistically insignificant at the $5 \%$-level except for a small positive association between flexi-time and actual hours for males. Flexi-time therefore does not seem to be associated with an increase in hours worked.

Overall, we cannot convincingly reject the null hypothesis of no effect of TLF on working hours. Even though we do find some small, positive associations between TLF and working hours here and there, the bigger picture is that after considering and controlling for mitigating factors, such as preferences, job, and household characteristics, the association between TLF and working hours vanishes (almost) completely. In addition, our sensitivity analyses do not reveal systematic differences in the associations between TLF and working hours for different groups. So there is no convincing evidence to support the claim that more schedule and location flexibility leads to a larger supply of working hours in general.

The merits of this study are that we consider two TLF arrangements, namely flexi-time and telehomework, at the same time and that we utilised data spanning 12 years from different sectors. The results further indicate the importance of controlling for unobserved heterogeneity in jobs and individuals in these types of analyses. A limitation of our study is that we cannot completely rule out endogeneity and reverse causality and therefore do not identify a true causal effect. Since the association between TLF and working hours after controlling for several individual and job-related factors turns out to be almost absent, this does not seem to be a major issue, however. Future research could extend this analysis with other TLF arrangements, like self-scheduling or working time accounts.

Overall, the hypothesis that more temporal and locational flexibility of work leads to an increase in hours worked appears to be rejected. The findings suggest that TLF does not have significant effects on labour supply at the intensive margin with the 
exception of telehomework and actual hours. This implies that the arguments regarding increases in labour supply in the debate about policy support for TLF are not empirically supported. This does not take away that there may be other good reasons to support policies for more TLF, e.g. higher productivity (Bloom et al. 2015), increased job satisfaction and working-time fit (Possenriede and Plantenga 2014), and less absenteeism (Possenriede et al. 2014).

\section{Endnotes}

${ }^{1}$ Every employee who has worked for a company with ten or more employees for at least one year can request a working hours adjustment. This right can be exercised once a year. The employer may only dismiss a request if it is a severe impediment to business interest. The Working Hours Adjustment Act (Wet Aanpassing Arbeidsduur) has been effective since mid 2000. Equal treatment of part-time and full-time employees with respect to employment conditions is furthermore stipulated in the Equal Treatment Working Hours Act (Wet verbod op onderscheid naar arbeidsduur), effective since 1996.

${ }^{2}$ Flexible working times may also induce employees to travel to work earlier and leave from work later to avoid traffic congestion, increasing work duration as a result (Arnott et al. 1993; Gutiérrez-i-Puigarnau and van Ommeren 2010).

${ }^{3}$ Predictions differ depending on whether one distinguishes between monetary and time costs of commuting, whether workdays, daily and total hours are allowed to vary, and whether one considers a static or dynamic approach (See e.g. Manning 2003; Gutiérrez-i-Puigarnau and van Ommeren 2010; Black et al. 2014).

${ }^{4}$ The amount of commuting time is exaggerated in the figure for better visibility.

${ }^{5} \mathrm{We}$ assume here that individuals are able to choose their preferred levels of consumption and leisure without any other constraints of course. In addition, a decrease in commuting costs and thus a shift in the budget constraint to the right reduces the size of the kink in the budget line. This reduction of the fixed costs of work not only increases labour supply at the intensive margin, but also induces non-working individuals to participate and thus raises labour force participation as well (e.g. Oi 1976; Cogan 1981; Black et al. 2014). Since Dutch labour participation rates are relatively high already, though, we focus on the effects on hours worked in this study.

${ }^{6}$ Note that this model also captures workers who do not have binding private schedule constraints in the above sense, but just a preference for work at certain intervals, e.g. due to certain life-style choices. Nevertheless the degree to which private schedule constraints are binding certainly differs between workers and depends inter alia on whether they have care responsibilities or not.

${ }^{7}$ The panel formerly known as the OSA Labour Supply Panel is now conducted on behalf of the Social Cultureel Planbureau (http://www.scp.nl/english/). The data and its documentation are in Dutch.

${ }^{8}$ While the question refers to work at home and not explicitly to telework, it is the first question in the section titled "telework" in the survey. In addition, only $2.1 \%$ of the respondents who work at home do not use ICT. Hence we label this variable telehomework.

${ }^{9}$ Telehomeworkers were asked how often they were working at home on average. From 2004 onwards the answer categories were less than once per month, less than twice per 
month, once per week or twice or more often per week. We only count the latter two categories as telehomeworkers. In 2002 the answer categories were once per month, twice per month, three times per month, more than three times per month. We include only the latter as telehomeworkers.

${ }^{10} \mathrm{~A}$ superscript to indicate the different outcome variables is omitted.

${ }^{11}$ We estimated the model with a random-effects specification as well. The crucial assumption of a random-effects specification, however, is that the individual-specific error term $\alpha_{i}$ is not correlated with the right-hand side variables $Z_{i t}$, otherwise the estimated coefficients will be biased. Since the availability and usage of TLF and the number of working hours quite likely depend on various job and individual characteristics this assumption seems rather strong. The random-effects specification was thus firmly rejected by a Hausman specification test in favour of the fixed-effects specification for all models and (sub-)samples considered.

${ }^{12}$ Note that since the flexi-time and telehomework indicators are binary, we effectively estimate linear probability models for these TLF variables. We do not control for the other TLF arrangement in these models (i.e. flexi-time is not controlled for in the telehomework regression and vice versa). The linear probability models for flexi-time behave well, as no observations are predicted outside the unit-interval. For telehomework, only $4.4 \%, 12.8 \%$, and $9.3 \%$ of the observations are predicted outside the unit-interval for the total, male, and female sample respectively.

${ }^{13}$ The random-effects specification was again firmly rejected by a Hausman specification test for all samples.

${ }^{14}$ The division bias refers to the fact that hourly wages are calculated by dividing net wages per month by hours per month. This causes measurement error in hours to enter both sides of Eq. 4 and results in a spurious negative correlation between wages and hours.

${ }^{15}$ We use the same control variables as in the baseline specification in this and all following specifications in this paragraph.

${ }^{16}$ In their study on labour supply and commuting, Gutiérrez-i-Puigarnau and van Ommeren (2010) also find that the inclusion of an instrumented wage variable does not affect their results.

${ }^{17}$ Note however that more than half of the employees for which TLF status changes have no change in their employment status. This indicates that a considerable share of employees in our sample does not seem to make these choices simultaneously.

${ }^{18}$ It might seem desirable to estimate this model on the sub-sample of part-time working (female) employees as well. Part-time employment may be an alternative strategy to combine work and private life and one thus might expect the largest effects of schedule and location flexibility here. Empirically, this is incorrect, however, because one would select the sample on the dependent variable and thus get biased estimates. Furthermore we are interested in the net effect of TLF, not just the effect on part-timers. Given the distribution of working hours across gender in the Netherlands, i.e. male employees mostly working full-time and female employees mostly working part-time, one could interpret gender as a proxy for part-time/full-time employment, however.

${ }^{19}$ We estimated a model like Eq. 4 on paid and unpaid overtime hours. These results are only indicative, however, due to the large number of employees with zero overtime hours. Estimates are therefore not shown. 


\section{Appendix}

Table 11 Control variables on working hours

\begin{tabular}{|c|c|c|c|c|c|c|c|c|c|}
\hline & \multicolumn{3}{|c|}{ Actual hours } & \multicolumn{3}{|c|}{ Contracted hours } & \multicolumn{3}{|c|}{ Preferred hours } \\
\hline & Total & Male & Female & Total & Male & Female & Total & Male & Female \\
\hline \multirow[t]{2}{*}{ Age } & -0.019 & $-0.133^{*}$ & $0.127^{*}$ & 0.004 & -0.080 & $0.108^{* *}$ & $0.134^{* *}$ & $0.114^{*}$ & $0.167^{* *}$ \\
\hline & $(0.040)$ & $(0.057)$ & $(0.056)$ & $(0.029)$ & $(0.042)$ & $(0.041)$ & $(0.037)$ & $(0.056)$ & $(0.049)$ \\
\hline \multicolumn{10}{|l|}{ Marital status } \\
\hline \multicolumn{10}{|l|}{ Ref: Married } \\
\hline \multirow[t]{2}{*}{ Cohabiting } & 0.909 & -0.356 & $2.244^{* *}$ & 0.707 & -0.491 & $1.912^{* *}$ & 0.488 & -0.530 & $1.487^{*}$ \\
\hline & $(0.491)$ & $(0.559)$ & $(0.770)$ & $(0.374)$ & $(0.362)$ & $(0.608)$ & $(0.459)$ & $(0.573)$ & $(0.697)$ \\
\hline \multirow[t]{2}{*}{ Single } & 1.114 & $-1.676^{*}$ & $3.100^{* *}$ & $1.090^{*}$ & -0.268 & $2.207^{* *}$ & $1.793^{* *}$ & 0.594 & $2.807^{* *}$ \\
\hline & $(0.699)$ & $(0.814)$ & $(1.001)$ & $(0.548)$ & $(0.449)$ & $(0.852)$ & $(0.597)$ & $(0.585)$ & $(0.911)$ \\
\hline \multirow[t]{2}{*}{ Child(ren) } & $-1.063^{* *}$ & 0.111 & $-2.238^{* *}$ & $-0.886^{* *}$ & 0.390 & $-2.185^{* *}$ & $-0.689^{* *}$ & 0.302 & $-1.703^{* *}$ \\
\hline & $(0.257)$ & $(0.306)$ & $(0.403)$ & $(0.207)$ & $(0.224)$ & $(0.334)$ & $(0.249)$ & $(0.326)$ & $(0.358)$ \\
\hline \multicolumn{10}{|l|}{ Education } \\
\hline \multicolumn{10}{|l|}{ Ref: Primary School } \\
\hline \multirow[t]{2}{*}{ Lower secondary } & 1.543 & 0.850 & 2.029 & 0.961 & 0.295 & 1.841 & 1.118 & 0.720 & 1.434 \\
\hline & $(1.006)$ & $(1.224)$ & $(1.722)$ & $(0.836)$ & $(1.038)$ & $(1.320)$ & $(0.943)$ & $(1.245)$ & $(1.263)$ \\
\hline \multirow[t]{2}{*}{ Higher secondary } & $2.126^{*}$ & 0.754 & 3.462 & 1.438 & 0.438 & $2.775^{*}$ & $1.950^{*}$ & 1.147 & $2.823^{*}$ \\
\hline & $(1.077)$ & $(1.312)$ & $(1.820)$ & $(0.878)$ & $(1.083)$ & (1.393) & $(0.988)$ & $(1.303)$ & (1.338) \\
\hline \multirow[t]{2}{*}{ Vocational college } & $4.418^{* *}$ & 2.623 & $6.191^{* *}$ & $3.118^{* *}$ & 1.610 & $4.957^{* *}$ & $3.237^{* *}$ & 1.957 & $4.572^{* *}$ \\
\hline & $(1.180)$ & $(1.447)$ & $(1.965)$ & $(0.963)$ & $(1.182)$ & $(1.535)$ & $(1.064)$ & $(1.387)$ & $(1.490)$ \\
\hline \multirow[t]{2}{*}{ Academic } & $4.864^{* *}$ & 3.086 & $6.512^{* *}$ & $3.742^{* *}$ & 1.904 & $6.001^{* *}$ & $4.233^{* *}$ & 2.608 & $6.088^{* *}$ \\
\hline & $(1.356)$ & $(1.661)$ & $(2.274)$ & $(1.098)$ & $(1.312)$ & $(1.810)$ & $(1.190)$ & $(1.508)$ & $(1.772)$ \\
\hline \multirow[t]{2}{*}{ Work experience } & 0.008 & -0.006 & 0.009 & -0.007 & -0.011 & -0.011 & -0.017 & -0.021 & -0.021 \\
\hline & $(0.028)$ & $(0.042)$ & $(0.039)$ & $(0.019)$ & $(0.030)$ & $(0.024)$ & $(0.025)$ & $(0.039)$ & $(0.033)$ \\
\hline \multirow[t]{2}{*}{ Permanent contract } & $0.873^{* *}$ & 0.604 & $1.005^{*}$ & $0.599^{*}$ & 0.664 & 0.407 & -0.020 & -0.118 & -0.049 \\
\hline & $(0.329)$ & $(0.465)$ & $(0.447)$ & $(0.276)$ & $(0.379)$ & $(0.381)$ & $(0.296)$ & $(0.438)$ & $(0.392)$ \\
\hline
\end{tabular}


Table 11 Control variables on working hours (Continuation)

\begin{tabular}{|c|c|c|c|c|c|c|c|c|c|}
\hline \multirow[t]{2}{*}{ Empl. status change } & 0.222 & -0.256 & $0.645^{* *}$ & 0.092 & -0.170 & 0.314 & 0.093 & -0.107 & 0.228 \\
\hline & $(0.158)$ & $(0.223)$ & $(0.217)$ & $(0.118)$ & $(0.157)$ & $(0.171)$ & $(0.146)$ & $(0.213)$ & $(0.196)$ \\
\hline \multirow[t]{2}{*}{ 2nd job } & $-0.913^{*}$ & -1.045 & -1.015 & $-1.419^{* *}$ & $-1.808^{* *}$ & $-1.285^{*}$ & $-1.202^{* *}$ & $-1.541^{*}$ & -1.116 \\
\hline & $(0.448)$ & $(0.716)$ & $(0.563)$ & $(0.403)$ & $(0.565)$ & $(0.551)$ & $(0.423)$ & $(0.604)$ & $(0.579)$ \\
\hline \multicolumn{10}{|l|}{ Supervised employees } \\
\hline \multicolumn{10}{|l|}{ Ref: None } \\
\hline \multirow[t]{2}{*}{ 1-9 employees } & $1.192^{* *}$ & $0.929^{* *}$ & $1.434^{* *}$ & $0.542^{* *}$ & 0.331 & $0.715^{* *}$ & $0.385^{*}$ & 0.151 & $0.651^{*}$ \\
\hline & $(0.213)$ & $(0.253)$ & $(0.348)$ & $(0.152)$ & $(0.170)$ & $(0.263)$ & $(0.180)$ & $(0.231)$ & $(0.278)$ \\
\hline \multirow[t]{2}{*}{ 10-49 employees } & $2.006^{* *}$ & $1.917^{* *}$ & $2.000^{* *}$ & $0.672^{* *}$ & 0.465 & 0.876 & $0.722^{*}$ & $0.773^{*}$ & 0.443 \\
\hline & $(0.376)$ & $(0.423)$ & $(0.697)$ & $(0.248)$ & $(0.264)$ & $(0.490)$ & $(0.302)$ & $(0.352)$ & $(0.556)$ \\
\hline \multirow[t]{2}{*}{50 or more employees } & $3.045^{* *}$ & $3.113^{* *}$ & 2.506 & 1.397 & $1.472^{*}$ & 0.935 & 1.253 & $2.165^{* *}$ & -1.722 \\
\hline & $(0.805)$ & $(0.866)$ & $(1.683)$ & $(0.717)$ & $(0.600)$ & $(2.005)$ & $(0.875)$ & $(0.771)$ & (2.327) \\
\hline \multicolumn{10}{|l|}{ Occupational level } \\
\hline \multicolumn{10}{|l|}{ Ref: Medium } \\
\hline \multirow[t]{2}{*}{ Elementary } & $-1.711^{* *}$ & $-2.418^{* *}$ & -1.180 & $-1.197^{*}$ & $-1.759^{* *}$ & -0.627 & $-1.138^{*}$ & $-1.750^{* *}$ & -0.588 \\
\hline & $(0.606)$ & $(0.810)$ & $(0.943)$ & $(0.488)$ & $(0.594)$ & $(0.813)$ & $(0.520)$ & $(0.591)$ & $(0.904)$ \\
\hline \multirow[t]{2}{*}{ Lower } & $-0.687^{* *}$ & $-0.613^{*}$ & -0.572 & $-0.556^{* *}$ & $-0.631^{* *}$ & -0.330 & -0.195 & -0.189 & -0.086 \\
\hline & $(0.205)$ & $(0.275)$ & $(0.297)$ & $(0.169)$ & $(0.219)$ & $(0.249)$ & $(0.206)$ & (0.309) & $(0.273)$ \\
\hline \multirow[t]{2}{*}{ Higher } & $0.439^{*}$ & 0.365 & 0.368 & $0.332^{*}$ & 0.289 & 0.300 & 0.230 & 0.221 & 0.153 \\
\hline & $(0.195)$ & $(0.255)$ & $(0.304)$ & $(0.157)$ & $(0.192)$ & $(0.255)$ & $(0.191)$ & $(0.246)$ & $(0.296)$ \\
\hline \multirow[t]{2}{*}{ Scientific } & 0.446 & 0.731 & -0.160 & $0.430^{*}$ & $0.561^{*}$ & 0.152 & 0.270 & 0.297 & 0.220 \\
\hline & $(0.331)$ & $(0.415)$ & $(0.548)$ & $(0.212)$ & $(0.264)$ & $(0.351)$ & $(0.284)$ & $(0.348)$ & $(0.486)$ \\
\hline \multicolumn{10}{|l|}{ Sector } \\
\hline \multicolumn{10}{|l|}{ Ref: Agriculture } \\
\hline \multirow[t]{2}{*}{ Industry } & 0.585 & -1.488 & 4.033 & 1.481 & -0.158 & 4.651 & 0.543 & -0.868 & 3.300 \\
\hline & $(1.414)$ & $(1.277)$ & $(2.298)$ & $(1.066)$ & $(0.631)$ & $(2.407)$ & $(1.064)$ & $(0.874)$ & (2.223) \\
\hline \multirow[t]{2}{*}{ Construction } & 0.672 & -1.236 & 3.563 & $2.426^{*}$ & 0.869 & $5.346^{*}$ & 1.143 & -0.109 & 3.273 \\
\hline & (1.510) & $(1.390)$ & $(2.531)$ & (1.104) & $(0.703)$ & $(2.708)$ & $(1.092)$ & $(0.901)$ & (2.552) \\
\hline
\end{tabular}


Table 11 Control variables on working hours (Continuation)

\begin{tabular}{|c|c|c|c|c|c|c|c|c|c|}
\hline \multirow[t]{2}{*}{ Trade, gastronomy, repair } & -0.329 & -2.239 & 3.270 & 0.687 & -0.859 & 4.019 & -0.037 & -1.355 & 2.771 \\
\hline & $(1.443)$ & $(1.315)$ & $(2.348)$ & $(1.091)$ & $(0.663)$ & $(2.439)$ & $(1.087)$ & $(0.928)$ & $(2.217)$ \\
\hline \multirow[t]{2}{*}{ Transport } & 1.232 & -1.174 & $6.029^{*}$ & 1.863 & -0.480 & $7.176^{* *}$ & 0.557 & -1.193 & 4.303 \\
\hline & $(1.549)$ & $(1.466)$ & $(2.669)$ & $(1.216)$ & $(0.886)$ & $(2.740)$ & $(1.218)$ & $(1.104)$ & $(2.519)$ \\
\hline \multirow[t]{2}{*}{ Business services } & 0.946 & -1.574 & $5.408^{*}$ & 1.856 & 0.101 & $5.490^{*}$ & 0.774 & -0.642 & 3.686 \\
\hline & $(1.431)$ & $(1.271)$ & $(2.390)$ & $(1.071)$ & $(0.638)$ & $(2.440)$ & $(1.075)$ & $(0.877)$ & $(2.258)$ \\
\hline \multirow[t]{2}{*}{ Care, Welfare } & 1.132 & -2.315 & $5.693^{*}$ & 1.737 & -1.029 & $5.751^{*}$ & 1.100 & -1.355 & $4.539^{*}$ \\
\hline & $(1.480)$ & $(1.405)$ & $(2.436)$ & $(1.143)$ & $(0.876)$ & $(2.512)$ & $(1.157)$ & $(1.179)$ & $(2.308)$ \\
\hline \multirow[t]{2}{*}{ Other services } & 0.550 & -2.198 & $5.276^{*}$ & 0.957 & -0.975 & 4.693 & 0.256 & -1.449 & 3.464 \\
\hline & $(1.479)$ & $(1.421)$ & $(2.409)$ & $(1.130)$ & $(0.795)$ & $(2.514)$ & $(1.169)$ & $(1.117)$ & $(2.332)$ \\
\hline \multirow[t]{2}{*}{ Government } & 0.820 & -1.493 & $4.893^{*}$ & 1.114 & -0.677 & 4.641 & 0.695 & -0.945 & 3.706 \\
\hline & $(1.435)$ & $(1.317)$ & $(2.431)$ & $(1.089)$ & $(0.723)$ & $(2.473)$ & $(1.099)$ & $(0.958)$ & $(2.280)$ \\
\hline \multirow[t]{2}{*}{ Education } & $3.385^{*}$ & 0.211 & $8.378^{* *}$ & $3.113^{*}$ & 0.392 & $7.588^{* *}$ & 2.172 & -0.972 & $6.575^{* *}$ \\
\hline & $(1.618)$ & $(1.732)$ & $(2.588)$ & $(1.232)$ & $(1.002)$ & $(2.612)$ & $(1.269)$ & $(1.237)$ & $(2.454)$ \\
\hline \multirow[t]{2}{*}{ No. of employees (/1000) } & 0.028 & 0.057 & -0.023 & 0.012 & 0.031 & -0.015 & 0.023 & 0.036 & 0.012 \\
\hline & $(0.027)$ & $(0.030)$ & $(0.053)$ & $(0.020)$ & $(0.022)$ & $(0.046)$ & $(0.028)$ & $(0.031)$ & $(0.063)$ \\
\hline \multirow[t]{2}{*}{ Constant } & $29.244^{* *}$ & $44.843^{* *}$ & $10.543^{* *}$ & $26.949^{* *}$ & $38.964^{* *}$ & $11.790^{* *}$ & $21.937^{* *}$ & $30.435^{* *}$ & $11.183^{* *}$ \\
\hline & $(2.238)$ & (2.588) & (3.593) & $(1.736)$ & $(1.809)$ & (3.259) & $(1.965)$ & $(2.505)$ & $(3.215)$ \\
\hline Observations & 14046 & 7325 & 6721 & 16022 & 8299 & 7723 & 16022 & 8299 & 7723 \\
\hline Individuals & 6409 & 3333 & 3076 & 7164 & 3681 & 3483 & 7164 & 3681 & 3483 \\
\hline
\end{tabular}

Note: Parameter estimates of control variables only on working hours. Year (wave) dummies included. Standard errors in parentheses (clustered at employee level) ${ }^{*} p<0.05,{ }^{* *} p<0.01$ 
Table 12 Control variables on TLF arrangements

\begin{tabular}{|c|c|c|c|c|c|c|}
\hline & \multicolumn{3}{|c|}{ Flexi-time } & \multicolumn{3}{|c|}{ Telehomework } \\
\hline & Total & Male & Female & Total & Male & Female \\
\hline \multirow[t]{2}{*}{ Age } & 0.004 & 0.003 & 0.005 & $0.006^{* *}$ & 0.005 & $0.008^{* *}$ \\
\hline & $(0.002)$ & $(0.003)$ & $(0.003)$ & $(0.002)$ & $(0.002)$ & $(0.002)$ \\
\hline \multicolumn{7}{|l|}{ Marital status } \\
\hline \multicolumn{7}{|l|}{ Ref: Married } \\
\hline \multirow[t]{2}{*}{ Cohabiting } & -0.049 & -0.054 & -0.043 & -0.024 & -0.060 & 0.011 \\
\hline & $(0.026)$ & $(0.040)$ & $(0.034)$ & $(0.021)$ & $(0.031)$ & $(0.029)$ \\
\hline \multirow[t]{2}{*}{ Single } & -0.056 & -0.101 & -0.021 & -0.038 & $-0.096^{*}$ & 0.009 \\
\hline & $(0.033)$ & $(0.056)$ & $(0.038)$ & $(0.024)$ & $(0.043)$ & $(0.028)$ \\
\hline \multirow[t]{2}{*}{ Child(ren) } & 0.024 & 0.036 & 0.013 & $0.030^{*}$ & $0.050^{* *}$ & 0.008 \\
\hline & $(0.015)$ & $(0.023)$ & $(0.020)$ & $(0.013)$ & $(0.018)$ & $(0.018)$ \\
\hline \multicolumn{7}{|l|}{ Education } \\
\hline \multicolumn{7}{|l|}{ Ref: Primary School } \\
\hline \multirow[t]{2}{*}{ Lower secondary } & -0.012 & 0.037 & -0.130 & -0.021 & 0.003 & -0.074 \\
\hline & $(0.039)$ & $(0.038)$ & $(0.081)$ & $(0.022)$ & $(0.026)$ & $(0.038)$ \\
\hline \multirow[t]{2}{*}{ Higher secondary } & -0.033 & 0.027 & -0.161 & -0.013 & 0.010 & -0.062 \\
\hline & $(0.042)$ & $(0.042)$ & $(0.088)$ & $(0.024)$ & $(0.031)$ & $(0.038)$ \\
\hline \multirow[t]{2}{*}{ Vocational college } & -0.018 & 0.037 & -0.138 & -0.007 & 0.068 & $-0.116^{*}$ \\
\hline & $(0.048)$ & $(0.052)$ & $(0.093)$ & $(0.031)$ & $(0.042)$ & $(0.046)$ \\
\hline \multirow[t]{2}{*}{ Academic } & -0.023 & -0.005 & -0.094 & 0.017 & 0.051 & -0.036 \\
\hline & $(0.056)$ & $(0.067)$ & $(0.101)$ & $(0.046)$ & $(0.061)$ & $(0.070)$ \\
\hline \multirow[t]{2}{*}{ Work experience } & -0.000 & 0.002 & -0.003 & -0.000 & -0.000 & -0.000 \\
\hline & $(0.001)$ & $(0.002)$ & $(0.002)$ & $(0.001)$ & $(0.002)$ & $(0.001)$ \\
\hline \multirow[t]{2}{*}{ Permanent contract } & 0.020 & -0.004 & 0.039 & 0.008 & -0.000 & 0.012 \\
\hline & $(0.017)$ & $(0.025)$ & $(0.022)$ & $(0.012)$ & $(0.019)$ & $(0.016)$ \\
\hline
\end{tabular}


Table 12 Control variables on TLF arrangements (Continuation)

\begin{tabular}{|c|c|c|c|c|c|c|}
\hline Empl. status change & $\begin{array}{l}0.014 \\
(0.009)\end{array}$ & $\begin{array}{l}0.015 \\
(0.014)\end{array}$ & $\begin{array}{l}0.011 \\
(0.013)\end{array}$ & $\begin{array}{l}0.012 \\
(0.008)\end{array}$ & $\begin{array}{l}0.010 \\
(0.012)\end{array}$ & $\begin{array}{l}0.014 \\
(0.011)\end{array}$ \\
\hline 2nd job & $\begin{array}{l}0.009 \\
(0.021)\end{array}$ & $\begin{array}{l}-0.012 \\
(0.034)\end{array}$ & $\begin{array}{l}0.021 \\
(0.027)\end{array}$ & $\begin{array}{l}-0.011 \\
(0.018)\end{array}$ & $\begin{array}{l}-0.050 \\
(0.033)\end{array}$ & $\begin{array}{l}0.013 \\
(0.021)\end{array}$ \\
\hline \multicolumn{7}{|l|}{ Supervised employees } \\
\hline 1-9 employees & $\begin{array}{l}0.034^{*} \\
(0.013)\end{array}$ & $\begin{array}{l}0.019 \\
(0.017)\end{array}$ & $\begin{array}{l}0.057^{* *} \\
(0.021)\end{array}$ & $\begin{array}{l}0.028^{*} \\
(0.012)\end{array}$ & $\begin{array}{l}0.016 \\
(0.016)\end{array}$ & $\begin{array}{l}0.040^{*} \\
(0.018)\end{array}$ \\
\hline 10-49 employees & $\begin{array}{l}0.059^{* *} \\
(0.022)\end{array}$ & $\begin{array}{l}0.065^{*} \\
(0.029)\end{array}$ & $\begin{array}{l}0.042 \\
(0.034)\end{array}$ & $\begin{array}{l}0.047^{*} \\
(0.021)\end{array}$ & $\begin{array}{l}0.017 \\
(0.025)\end{array}$ & $\begin{array}{l}0.089^{*} \\
(0.035)\end{array}$ \\
\hline 50 or more employees & $\begin{array}{l}0.022 \\
(0.046)\end{array}$ & $\begin{array}{l}0.030 \\
(0.055)\end{array}$ & $\begin{array}{l}-0.008 \\
(0.081)\end{array}$ & $\begin{array}{l}0.056 \\
(0.046)\end{array}$ & $\begin{array}{l}0.038 \\
(0.055)\end{array}$ & $\begin{array}{l}0.056 \\
(0.080)\end{array}$ \\
\hline \multicolumn{7}{|l|}{ Ref: Medium } \\
\hline Elementary & $\begin{array}{l}-0.057^{*} \\
(0.027)\end{array}$ & $\begin{array}{l}-0.106^{* *} \\
(0.034)\end{array}$ & $\begin{array}{l}0.001 \\
(0.043)\end{array}$ & $\begin{array}{l}-0.001 \\
(0.013)\end{array}$ & $\begin{array}{l}0.016 \\
(0.018)\end{array}$ & $\begin{array}{l}-0.021 \\
(0.019)\end{array}$ \\
\hline Lower & $\begin{array}{l}-0.044^{* *} \\
(0.013)\end{array}$ & $\begin{array}{l}-0.051^{* *} \\
(0.019)\end{array}$ & $\begin{array}{l}-0.034 \\
(0.018)\end{array}$ & $\begin{array}{l}-0.016 \\
(0.009)\end{array}$ & $\begin{array}{l}-0.014 \\
(0.012)\end{array}$ & $\begin{array}{l}-0.019 \\
(0.013)\end{array}$ \\
\hline Higher & $\begin{array}{l}0.019 \\
(0.014)\end{array}$ & $\begin{array}{l}0.021 \\
(0.018)\end{array}$ & $\begin{array}{l}0.014 \\
(0.020)\end{array}$ & $\begin{array}{l}0.006 \\
(0.012)\end{array}$ & $\begin{array}{l}0.001 \\
(0.016)\end{array}$ & $\begin{array}{l}0.012 \\
(0.019)\end{array}$ \\
\hline Scientific & $\begin{array}{l}0.027 \\
(0.020)\end{array}$ & $\begin{array}{l}0.039 \\
(0.025)\end{array}$ & $\begin{array}{l}0.005 \\
(0.033)\end{array}$ & $\begin{array}{l}-0.028 \\
(0.020)\end{array}$ & $\begin{array}{l}-0.036 \\
(0.025)\end{array}$ & $\begin{array}{l}-0.013 \\
(0.034)\end{array}$ \\
\hline \multicolumn{7}{|l|}{ Ref: Agriculture } \\
\hline Industry & $\begin{array}{l}-0.144 \\
(0.081)\end{array}$ & $\begin{array}{l}-0.143 \\
(0.089)\end{array}$ & $\begin{array}{l}-0.116 \\
(0.181)\end{array}$ & $\begin{array}{l}-0.032 \\
(0.033)\end{array}$ & $\begin{array}{l}-0.053 \\
(0.045)\end{array}$ & $\begin{array}{l}0.013 \\
(0.041)\end{array}$ \\
\hline Construction & $\begin{array}{l}-0.137 \\
(0.085)\end{array}$ & $\begin{array}{l}-0.143 \\
(0.091)\end{array}$ & $\begin{array}{l}-0.040 \\
(0.222)\end{array}$ & $\begin{array}{l}-0.017 \\
(0.040)\end{array}$ & $\begin{array}{l}-0.034 \\
(0.049)\end{array}$ & $\begin{array}{l}0.030 \\
(0.113)\end{array}$ \\
\hline
\end{tabular}


Table 12 Control variables on TLF arrangements (Continuation)

\begin{tabular}{|c|c|c|c|c|c|c|}
\hline \multirow[t]{2}{*}{ Trade, gastronomy, repair } & $-0.178^{*}$ & -0.164 & -0.182 & -0.003 & -0.012 & 0.009 \\
\hline & $(0.081)$ & $(0.090)$ & $(0.175)$ & $(0.034)$ & $(0.048)$ & $(0.038)$ \\
\hline \multirow[t]{2}{*}{ Transport } & -0.137 & -0.127 & -0.136 & -0.014 & -0.018 & -0.009 \\
\hline & $(0.086)$ & $(0.097)$ & $(0.181)$ & $(0.038)$ & $(0.052)$ & $(0.049)$ \\
\hline \multirow[t]{2}{*}{ Business services } & -0.123 & -0.114 & -0.120 & -0.023 & -0.043 & 0.008 \\
\hline & $(0.080)$ & $(0.087)$ & $(0.174)$ & $(0.032)$ & $(0.044)$ & $(0.039)$ \\
\hline \multirow[t]{2}{*}{ Care, Welfare } & -0.091 & -0.088 & -0.085 & 0.001 & 0.055 & -0.002 \\
\hline & $(0.084)$ & $(0.098)$ & $(0.177)$ & $(0.040)$ & $(0.062)$ & $(0.044)$ \\
\hline \multirow[t]{2}{*}{ Other services } & -0.139 & -0.067 & -0.234 & 0.011 & -0.004 & 0.037 \\
\hline & $(0.083)$ & $(0.095)$ & $(0.175)$ & $(0.040)$ & $(0.054)$ & $(0.053)$ \\
\hline \multirow[t]{2}{*}{ Government } & -0.087 & -0.103 & -0.053 & -0.010 & -0.017 & 0.011 \\
\hline & $(0.083)$ & $(0.092)$ & $(0.179)$ & $(0.039)$ & $(0.050)$ & $(0.056)$ \\
\hline \multirow[t]{2}{*}{ Education } & -0.145 & -0.193 & -0.099 & -0.010 & -0.096 & 0.069 \\
\hline & $(0.089)$ & $(0.103)$ & $(0.182)$ & $(0.047)$ & $(0.060)$ & $(0.062)$ \\
\hline \multirow[t]{2}{*}{ No. of employees (/1000) } & 0.001 & 0.001 & 0.001 & 0.003 & 0.002 & 0.006 \\
\hline & $(0.001)$ & $(0.001)$ & $(0.003)$ & $(0.002)$ & $(0.002)$ & $(0.004)$ \\
\hline \multirow[t]{2}{*}{ Constant } & $0.336^{* *}$ & $0.362^{*}$ & 0.374 & -0.071 & -0.005 & -0.117 \\
\hline & $(0.115)$ & $(0.144)$ & $(0.211)$ & $(0.073)$ & $(0.105)$ & $(0.102)$ \\
\hline Observations & 16022 & 8299 & 7723 & 16022 & 8299 & 7723 \\
\hline Individuals & 7164 & 3681 & 3483 & 7164 & 3681 & 3483 \\
\hline
\end{tabular}

Note: Parameter estimates of control variables on flexi-time and telehomework. Year (wave) dummies included. Standard errors in parentheses (clustered at employee level)

${ }^{*} p<0.05,{ }^{* *} p<0.01$ 
Table 13 TLF arrangements on working hours

\begin{tabular}{|c|c|c|c|c|c|c|c|c|c|}
\hline & \multicolumn{3}{|c|}{ Actual hours } & \multicolumn{3}{|c|}{ Contracted hours } & \multicolumn{3}{|c|}{ Preferred hours } \\
\hline & Total & Male & Female & Total & Male & Female & Total & Male & Female \\
\hline \multirow[t]{2}{*}{ Flexi-time } & 0.223 & $0.555^{*}$ & -0.189 & -0.094 & 0.151 & -0.396 & -0.055 & 0.269 & -0.484 \\
\hline & $(0.208)$ & $(0.278)$ & $(0.307)$ & $(0.153)$ & $(0.183)$ & $(0.247)$ & $(0.186)$ & $(0.255)$ & $(0.266)$ \\
\hline \multirow[t]{2}{*}{ Telehomework } & $0.920^{* *}$ & $0.681^{*}$ & $1.103^{* *}$ & 0.291 & 0.010 & $0.501^{*}$ & 0.366 & 0.183 & 0.474 \\
\hline & $(0.218)$ & $(0.298)$ & $(0.312)$ & $(0.150)$ & $(0.182)$ & $(0.241)$ & (0.199) & $(0.275)$ & $(0.281)$ \\
\hline \multirow[t]{2}{*}{ Age } & -0.029 & $-0.139^{*}$ & $0.113^{*}$ & 0.003 & -0.080 & $0.106^{* *}$ & $0.133^{* *}$ & $0.112^{*}$ & $0.166^{* *}$ \\
\hline & $(0.040)$ & $(0.057)$ & $(0.056)$ & $(0.029)$ & $(0.042)$ & $(0.041)$ & $(0.037)$ & $(0.056)$ & $(0.049)$ \\
\hline \multicolumn{10}{|l|}{ Marital status } \\
\hline \multicolumn{10}{|l|}{ Ref: Married } \\
\hline \multirow[t]{2}{*}{ Cohabiting } & 0.945 & -0.284 & $2.230^{* *}$ & 0.709 & -0.483 & $1.890^{* *}$ & 0.494 & -0.505 & $1.461^{*}$ \\
\hline & $(0.489)$ & $(0.556)$ & $(0.769)$ & $(0.374)$ & $(0.363)$ & $(0.608)$ & $(0.458)$ & $(0.571)$ & $(0.697)$ \\
\hline \multirow[t]{2}{*}{ Single } & 1.154 & -1.570 & $3.087^{* *}$ & $1.096^{*}$ & -0.252 & $2.194^{*}$ & $1.804^{* *}$ & 0.639 & $2.793^{* *}$ \\
\hline & $(0.699)$ & $(0.810)$ & $(1.001)$ & $(0.548)$ & $(0.448)$ & $(0.854)$ & $(0.596)$ & $(0.583)$ & $(0.913)$ \\
\hline \multirow[t]{2}{*}{ Child(ren) } & $-1.092^{* *}$ & 0.061 & $-2.249^{* *}$ & $-0.892^{* *}$ & 0.384 & $-2.183^{* *}$ & $-0.699^{* *}$ & 0.283 & $-1.700^{* *}$ \\
\hline & $(0.256)$ & $(0.306)$ & $(0.401)$ & $(0.207)$ & $(0.224)$ & $(0.334)$ & $(0.249)$ & $(0.324)$ & $(0.357)$ \\
\hline \multicolumn{10}{|l|}{ Education } \\
\hline \multicolumn{10}{|l|}{ Ref: Primary School } \\
\hline \multirow[t]{2}{*}{ Lower secondary } & 1.578 & 0.827 & 2.114 & 0.966 & 0.289 & 1.827 & 1.125 & 0.710 & 1.406 \\
\hline & $(1.008)$ & $(1.223)$ & $(1.716)$ & $(0.836)$ & $(1.038)$ & $(1.312)$ & $(0.942)$ & $(1.245)$ & $(1.250)$ \\
\hline \multirow[t]{2}{*}{ Higher secondary } & $2.165^{*}$ & 0.746 & 3.521 & 1.439 & 0.433 & $2.743^{*}$ & $1.952^{*}$ & 1.137 & $2.774^{*}$ \\
\hline & $(1.078)$ & $(1.310)$ & $(1.812)$ & $(0.877)$ & $(1.083)$ & $(1.383)$ & $(0.986)$ & $(1.302)$ & $(1.323)$ \\
\hline \multirow[t]{2}{*}{ Vocational college } & $4.451^{* *}$ & 2.562 & $6.307^{* *}$ & $3.119^{* *}$ & 1.604 & $4.961^{* *}$ & $3.239^{* *}$ & 1.934 & $4.560^{* *}$ \\
\hline & $(1.181)$ & $(1.444)$ & $(1.954)$ & $(0.963)$ & $(1.182)$ & $(1.525)$ & $(1.064)$ & $(1.387)$ & $(1.475)$ \\
\hline \multirow[t]{2}{*}{ Academic } & $4.865^{* *}$ & 3.053 & $6.544^{* *}$ & $3.735^{* *}$ & 1.905 & $5.981^{* *}$ & $4.226^{* *}$ & 2.600 & $6.060^{* *}$ \\
\hline & (1.357) & (1.660) & $(2.265)$ & (1.098) & $(1.312)$ & $(1.801)$ & (1.189) & (1.509) & (1.758) \\
\hline
\end{tabular}


Table 13 TLF arrangements on working hours (Continuation)

\begin{tabular}{|c|c|c|c|c|c|c|c|c|c|}
\hline \multirow[t]{2}{*}{ Work experience } & 0.009 & -0.007 & 0.010 & -0.007 & -0.011 & -0.012 & -0.017 & -0.022 & -0.022 \\
\hline & $(0.028)$ & $(0.042)$ & $(0.039)$ & $(0.019)$ & $(0.031)$ & $(0.024)$ & $(0.025)$ & $(0.039)$ & $(0.033)$ \\
\hline \multirow[t]{2}{*}{ Permanent contract } & $0.862^{* *}$ & 0.593 & $1.006^{*}$ & $0.599^{*}$ & 0.665 & 0.417 & -0.022 & -0.117 & -0.036 \\
\hline & $(0.329)$ & $(0.465)$ & $(0.446)$ & $(0.276)$ & $(0.379)$ & $(0.380)$ & $(0.296)$ & $(0.438)$ & $(0.390)$ \\
\hline \multirow[t]{2}{*}{ Empl. status change } & 0.212 & -0.271 & $0.637^{* *}$ & 0.089 & -0.173 & 0.311 & 0.089 & -0.113 & 0.227 \\
\hline & $(0.158)$ & $(0.222)$ & $(0.216)$ & $(0.118)$ & $(0.157)$ & $(0.171)$ & $(0.147)$ & $(0.214)$ & $(0.196)$ \\
\hline \multirow[t]{2}{*}{ 2nd job } & $-0.903^{*}$ & -1.020 & -1.013 & $-1.415^{* *}$ & $-1.806^{* *}$ & $-1.283^{*}$ & $-1.197^{* *}$ & $-1.529^{*}$ & -1.111 \\
\hline & $(0.449)$ & $(0.716)$ & $(0.563)$ & $(0.403)$ & $(0.564)$ & $(0.551)$ & $(0.423)$ & $(0.603)$ & $(0.579)$ \\
\hline \multicolumn{10}{|l|}{ Supervised employees } \\
\hline \multicolumn{10}{|l|}{ Ref: None } \\
\hline \multirow[t]{2}{*}{ 1-9 employees } & $1.155^{* *}$ & $0.902^{* *}$ & $1.408^{* *}$ & $0.537^{* *}$ & 0.328 & $0.717^{* *}$ & $0.376^{*}$ & 0.143 & $0.659^{*}$ \\
\hline & $(0.213)$ & $(0.252)$ & $(0.349)$ & $(0.152)$ & $(0.170)$ & $(0.264)$ & $(0.180)$ & $(0.231)$ & $(0.279)$ \\
\hline \multirow[t]{2}{*}{ 10-49 employees } & $1.965^{* *}$ & $1.880^{* *}$ & $1.928^{* *}$ & $0.664^{* *}$ & 0.455 & 0.848 & $0.708^{*}$ & $0.753^{*}$ & 0.421 \\
\hline & $(0.374)$ & $(0.420)$ & $(0.697)$ & $(0.248)$ & $(0.264)$ & $(0.491)$ & $(0.303)$ & $(0.353)$ & $(0.557)$ \\
\hline \multirow[t]{2}{*}{50 or more employees } & $2.980^{* *}$ & $3.047^{* *}$ & 2.418 & 1.382 & $1.467^{*}$ & 0.904 & 1.234 & $2.150^{* *}$ & -1.753 \\
\hline & $(0.802)$ & $(0.863)$ & $(1.687)$ & $(0.718)$ & $(0.601)$ & $(1.998)$ & $(0.874)$ & $(0.770)$ & $(2.320)$ \\
\hline \multicolumn{10}{|l|}{ Occupational level } \\
\hline \multicolumn{10}{|l|}{ Ref: Medium } \\
\hline \multirow[t]{2}{*}{ Elementary } & $-1.700^{* *}$ & $-2.381^{* *}$ & -1.145 & $-1.202^{*}$ & $-1.744^{* *}$ & -0.616 & $-1.141^{*}$ & $-1.724^{* *}$ & -0.577 \\
\hline & $(0.606)$ & $(0.809)$ & $(0.944)$ & $(0.488)$ & $(0.592)$ & $(0.811)$ & $(0.520)$ & $(0.593)$ & $(0.901)$ \\
\hline \multirow[t]{2}{*}{ Lower } & $-0.661^{* *}$ & $-0.577^{*}$ & -0.547 & $-0.555^{* *}$ & $-0.623^{* *}$ & -0.334 & -0.191 & -0.172 & -0.093 \\
\hline & $(0.206)$ & $(0.276)$ & $(0.297)$ & $(0.170)$ & $(0.220)$ & $(0.250)$ & $(0.207)$ & $(0.311)$ & $(0.273)$ \\
\hline \multirow[t]{2}{*}{ Higher } & $0.426^{*}$ & 0.348 & 0.358 & $0.332^{*}$ & 0.286 & 0.300 & 0.229 & 0.215 & 0.155 \\
\hline & $(0.195)$ & $(0.255)$ & $(0.302)$ & $(0.156)$ & $(0.192)$ & $(0.254)$ & $(0.191)$ & $(0.245)$ & $(0.296)$ \\
\hline \multirow[t]{2}{*}{ Scientific } & 0.470 & 0.735 & -0.137 & $0.441^{*}$ & $0.555^{*}$ & 0.161 & 0.282 & 0.293 & 0.229 \\
\hline & $(0.329)$ & $(0.415)$ & $(0.539)$ & $(0.212)$ & $(0.264)$ & $(0.348)$ & $(0.285)$ & $(0.348)$ & $(0.482)$ \\
\hline
\end{tabular}


Table 13 TLF arrangements on working hours (Continuation)

\begin{tabular}{|c|c|c|c|c|c|c|c|c|c|}
\hline \multicolumn{10}{|l|}{ Sector } \\
\hline \multicolumn{10}{|l|}{ Ref: Agriculture } \\
\hline \multirow[t]{2}{*}{ Industry } & 0.658 & -1.360 & 3.985 & 1.477 & -0.136 & 4.599 & 0.547 & -0.819 & 3.238 \\
\hline & $(1.420)$ & $(1.290)$ & $(2.312)$ & $(1.065)$ & $(0.630)$ & $(2.409)$ & $(1.062)$ & $(0.871)$ & $(2.207)$ \\
\hline \multirow[t]{2}{*}{ Construction } & 0.732 & -1.127 & 3.539 & $2.418^{*}$ & 0.891 & $5.315^{*}$ & 1.142 & -0.064 & 3.240 \\
\hline & $(1.514)$ & $(1.399)$ & $(2.541)$ & $(1.103)$ & $(0.701)$ & $(2.708)$ & $(1.090)$ & $(0.900)$ & $(2.542)$ \\
\hline \multirow[t]{2}{*}{ Trade, gastronomy, repair } & -0.274 & -2.123 & 3.220 & 0.672 & -0.834 & 3.942 & -0.046 & -1.309 & 2.679 \\
\hline & $(1.448)$ & $(1.327)$ & $(2.363)$ & $(1.090)$ & $(0.662)$ & $(2.441)$ & $(1.085)$ & $(0.927)$ & $(2.204)$ \\
\hline \multirow[t]{2}{*}{ Transport } & 1.280 & -1.096 & $6.021^{*}$ & 1.854 & -0.460 & $7.127^{* *}$ & 0.554 & -1.156 & 4.242 \\
\hline & $(1.554)$ & $(1.475)$ & $(2.686)$ & $(1.215)$ & $(0.886)$ & $(2.740)$ & $(1.216)$ & $(1.100)$ & $(2.504)$ \\
\hline \multirow[t]{2}{*}{ Business services } & 1.003 & -1.482 & $5.377^{*}$ & 1.851 & 0.118 & $5.439^{*}$ & 0.776 & -0.604 & 3.624 \\
\hline & $(1.436)$ & $(1.282)$ & $(2.405)$ & $(1.070)$ & $(0.637)$ & $(2.442)$ & $(1.074)$ & $(0.875)$ & $(2.247)$ \\
\hline \multirow[t]{2}{*}{ Care, Welfare } & 1.177 & -2.264 & $5.682^{*}$ & 1.729 & -1.017 & $5.719^{*}$ & 1.095 & -1.341 & 4.499 \\
\hline & $(1.484)$ & $(1.415)$ & $(2.451)$ & $(1.142)$ & $(0.875)$ & $(2.517)$ & $(1.155)$ & $(1.173)$ & $(2.298)$ \\
\hline \multirow[t]{2}{*}{ Other services } & 0.577 & -2.157 & $5.181^{*}$ & 0.941 & -0.965 & 4.581 & 0.244 & -1.430 & 3.333 \\
\hline & $(1.484)$ & $(1.434)$ & $(2.424)$ & $(1.129)$ & $(0.795)$ & $(2.516)$ & (1.168) & $(1.116)$ & $(2.320)$ \\
\hline \multirow[t]{2}{*}{ Government } & 0.867 & -1.396 & $4.881^{*}$ & 1.109 & -0.661 & 4.615 & 0.694 & -0.914 & 3.675 \\
\hline & $(1.440)$ & $(1.326)$ & (2.449) & $(1.088)$ & $(0.723)$ & $(2.478)$ & $(1.097)$ & $(0.956)$ & $(2.270)$ \\
\hline \multirow[t]{2}{*}{ Education } & $3.442^{*}$ & 0.363 & $8.314^{* *}$ & $3.102^{*}$ & 0.422 & $7.515^{* *}$ & 2.168 & -0.903 & $6.495^{* *}$ \\
\hline & $(1.620)$ & $(1.740)$ & $(2.597)$ & $(1.230)$ & (0.999) & $(2.613)$ & $(1.264)$ & $(1.234)$ & $(2.436)$ \\
\hline \multirow[t]{2}{*}{ No. of employees (/1000) } & 0.024 & 0.055 & -0.030 & 0.011 & 0.031 & -0.017 & 0.022 & 0.036 & 0.009 \\
\hline & $(0.026)$ & $(0.029)$ & $(0.051)$ & $(0.020)$ & $(0.022)$ & $(0.045)$ & $(0.028)$ & $(0.031)$ & $(0.064)$ \\
\hline \multirow[t]{2}{*}{ Constant } & $29.352^{* *}$ & $44.701^{* *}$ & $10.959^{* *}$ & $27.001^{* *}$ & $38.909^{* *}$ & $11.996 * *$ & $21.982^{* *}$ & $30.338^{* *}$ & $11.419^{* *}$ \\
\hline & $(2.239)$ & $(2.595)$ & (3.592) & $(1.732)$ & $(1.813)$ & $(3.250)$ & $(1.961)$ & $(2.507)$ & (3.197) \\
\hline Observations & 14046 & 7325 & 6721 & 16022 & 8299 & 7723 & 16022 & 8299 & 7723 \\
\hline Individuals & 6409 & 3333 & 3076 & 7164 & 3681 & 3483 & 7164 & 3681 & 3483 \\
\hline
\end{tabular}

Note: Parameter estimates of TLF arrangements on working hours. Year (wave) dummies included. Standard errors in parentheses (clustered at employee level) 


\section{Acknowledgements}

The authors would like to thank two anonymous referees as well as participants at ILERA European conference 2013 and IZA/RIETI workshop "Changing Demographics and the Labor Market" for valuable comments and suggestions. Data provision by Sociaal en Cultureel Planbureau and financial support by Instituut Gak are gratefully acknowledged. Responsible editor: Juan Jimeno

\section{Competing interests}

The IZA Journal of Labor Policy is committed to the IZA Guiding Principles of Research Integrity. The authors declares that they have observed these principles.

Received: 27 July 2015 Accepted: 24 June 2016

Published online: 26 August 2016

\section{References}

Akerlof GA (1982) Labor contracts as partial gift exchange. Q J Econ 97(4):543-569. http://www.jstor.org/stable/1885099

Altonji JG, Paxson CH (1988) Labor supply preferences, hours constraints, and hours-wage trade-offs. J Labor Econ 6(2):254-276. doi:10.2307/2535044 http://www.jstor.org/stable/2535044

Anderson DJ, Binder M, Krause K (2003) The motherhood wage penalty revisited: experience, heterogeneity, work effort, and work-schedule flexibility. Ind Labor Relat Rev 56(2):273-294. doi:10.2307/3590938. http://www.jstor.org/stable/ 3590938

Arnott R, Palma Ad, Lindsey R (1993) A structural model of peak-period congestion: a traffic bottleneck with elastic demand. Am Econ Rev 83(1):161-179. doi:10.2307/2117502. http://www.jstor.org/stable/2117502

Baltes BB, Briggs TE, Huff JW, Wright JA, Neuman GA (1999) Flexible and compressed workweek schedules: a meta-analysis of their effects on work-related criteria. J Appl Psychol 84(4):496-513. doi:10.1037/0021-9010.84.4.496 http://dx.doi.org/10.1037/0021-9010.84.4.496

Baughman R, DiNardi D, Holtz-Eakin D (2003) Productivity and wage effects of "family-friendly" fringe benefits. Int J Manpow 24(3):247-259. doi:10.1108/01437720310479723. http://dx.doi.org/10.1108/01437720310479723

Black DA, Kolesnikova N, Taylor LJ (2014) Why do so few women work in New York (and so many in Minneapolis)? Labor supply of married women across US cities. J Urban Econ 79:59-71. doi:10.1016/j.jue.2013.03.003. http://dx.doi.org/10. 1016/j.jue.2013.03.003

Blau FD, Kahn LM (2007) Changes in the labor supply behavior of married women 1980 -2000. J Labor Econ 25(3):393-438. doi:10.1086/513416. http://www.jstor.org/stable/10.1086/513416

Bloom N, Liang J, Roberts J, Ying ZJ (2015) Does working from home work? Evidence from a Chinese experiment. Q J Econ 130(1):165-218. doi:10.1093/qje/qju032. http://qje.oxfordjournals.org/content/130/1/165

BMFSFJ (2012) Zeit für Familie. Familienzeitpolitik als Chance einer nachhaltigen Familienpolitik. Achter Familienbericht. Bericht der Sachverstä, Bundesministerium für Familie, Senioren. Frauen und Jugend, Berlin. http://www.bmfsfj.de/ RedaktionBMFSFJ/Abteilung2/Pdf-Anlagen/Achter-familienbericht.pdf

Bonke J, Datta Gupta N, Smith N (2004) The timing and flexibility of housework and men and women's wages. In: Hamermesh DS, Pfann GA (eds). The economics of time use, Contributions to Economic Analysis. Elsevier, Amsterdam Vol. 271. pp 43-77. http://dx.doi.org/10.1016/S0573-8555(04)71003-2

Booth AL, van Ours JC (2013) Part-time jobs: what women want? J Popul Econ 26(1):263-283. doi:10.1007/s00148-012-0417-9. http://dx.doi.org/10.1007/s00148-012-0417-9

Borjas GJ (1980) The relationship between wages and weekly hours of work: the role of division bias. J Human Res 15(3):409-423. doi:10.2307/145291. http://www.jstor.org/stable/145291

Bosch G, Dawkings P, Michon F (1994) Times are changing. Working time in 14 industrialised countries. International Institute for Labour Studies - International Labour Organization (ILO), Geneva

Bosch N, Deelen A, Euwals R (2010) Is part-time employment here to stay? Working hours of Dutch women over successive generations. LABOUR 24(1):35-54. doi:10.1111/j.1467-9914.2010.00470.x. http://dx.doi.org/10.1111/j.1467-9914.2010. 00470.x

CEA (2010) Work-life balance and the economics of workplace flexibility. Executive Office of the President - Council of Economic Advisers, Washington, D.C. http://www.wh.gov/files/documents/100331-cea-economics-workplaceflexibility.pdf

Cloïn M, Schols M, van den Broek A (2010) Tijd op orde? Een analyse van de tijdsorde vanuit het perspectief van de burger. SCP-publicatie, Sociaal en Cultureel Planbureau, Den Haag. http://www.scp.nl/Publicaties/Alle_publicaties/ Publicaties_2010/Tijd_op_orde

Cogan JF (1981) Fixed costs and labor supply. Econometrica 49(4):945-963. doi:10.2307/1912512. http://www.jstor.org/ stable/1912512

Eaton SC (2003) If you can use them: flexibility policies, organizational commitment, and perceived performance. Ind Relat J Econ Soc 42(2):145-167. doi:10.1111/1468-232X.00285. http://dx.doi.org/10.1111/1468-232X.00285

Eldridge LP, Wulff Pabilonia S (2008) Are those who bring work home really working longer hours? Implications for BLS productivity measures. In: OECD (ed). Productivity measurement and analysis. OECD Publishing, Paris. pp 179-209. http://dx.doi.org/10.1787/9789264044616-10-en

Fagan C (2004) Gender and working time in industrialized countries. In: Messenger JC (ed). Working time and workers' preferences in industrialized countries. Finding the balance, Institute for Labour Studies of the International Labour Organisation series, Routledge. pp 108-146

Felstead A, Jewson N, Phizacklea A, Walters S (2002) The option to work at home: another privilege for the favoured few? New Technol Work Employment 17(3):204-223. doi:10.1111/1468-005X.00105. http://onlinelibrary.wiley.com/doi/10. 1111/1468-005X.00105/abstract 
Gajendran RS, Harrison DA (2007) The good, the bad, and the unknown about telecommuting: meta-analysis of psychological mediators and individual consequences. J Appl Psychol 92(6):1524-1541. doi:10.1037/0021-9010.92.6.1524. http://www.apa.org/pubs/journals/releases/apl-9261524.pdf

Gariety BS, Shaffer S (2001) Wage differentials associated with flextime. Mon Labor Rev 124(3):68-75. http://www.bls.gov/ opub/mlr/2001/03/art4full.pdf

Gariety BS, Shaffer S (2007) Wage differentials associated with working at home. Mon Labor Rev 130(3):61-67. http:// www.bls.gov/opub/mlr/2007/03/art5full.pdf

Gibbons S, Machin S (2006) Transport and labour market linkages: empirical evidence, implications for policy and scope for further research. Background Paper for the Eddington Report to the Department of Transport, HM Treasury, London. http://collections.europarchive.org/tna/20070402093752/http://www.hm-treasury.gov.uk/media/38C/A0/ eddington_researchannex1.2_011206.pdf

Golden L (1996) The economics of worktime length, adjustment, and flexibility. Rev Soc Econ 54(1):1-45. doi:10.1080/00346769600000001. http://dx.doi.org/10.1080/00346769600000001

Golden L (2006) Hours of labor supply. A more flexible approach. In: Altman M (ed). Handbook of contemporary behavioral economics. Foundations and developments. M.E. Sharpe, Armonk. pp 479-496

Golden L (2008) Limited access: Disparities in flexible work schedules and work-at-home. J Fam Econ Iss 29(1):86-109. doi:10.1007/s10834-007-9090-7. http://dx.doi.org/10.1007/s10834-007-9090-7

Golden L (2009) Flexible daily work schedules in U.S. jobs: formal introductions needed? Ind Relat J Econ Soc 48(1):27-54. doi:10.1111/j.1468-232X.2008.00544.x. http://dx.doi.org/10.1111/j.1468-232X.2008.00544.X

Gutiérrez-i-Puigarnau E, van Ommeren JN (2010) Labour supply and commuting. J Urban Econ 68(1):82-89. doi:10.1016/j.jue.2010.03.003. http://dx.doi.org/10.1016/j.jue.2010.03.003

Hassink WHJ, van den Berg B (2011) Time-bound opportunity costs of informal care: consequences for access to professional care, caregiver support, and labour supply estimates. Soc Sci Med 73(10):1508-1516. doi:10.1016/j.socscimed.2011.08.027. http://www.sciencedirect.com/science/article/pii/S027795361100534X

Heywood JS, Siebert WS, Wei X (2007) The implicit wage costs of family friendly work practices. Oxf Econ Pap 59(2):275-300. doi:10.1093/oep/gpm006. http://dx.doi.org/10.1093/oep/gpm006

Hill EJ, Miller BC, Weiner SP, Colihan J (1998) Influences of the virtual office on aspects of work and work/life balance. Pers Psychol 51(3):667-683. doi:10.1111/j.1744-6570.1998.tb00256.x. http://dx.doi.org/10.1111/j.1744-6570.1998.tb00256.x

Hill EJ, Grzywacz JG, Allen S, Blanchard VL, Matz-Costa C, Shulkin S, Pitt-Catsouphes M (2008) Defining and conceptualizing workplace flexibility. Commun Work Fam 11(2):149-163. doi:10.1080/13668800802024678. http://dx. doi.org/10.1080/13668800802024678

Johnson NB, Provan KG (1995) The relationship between work/family benefits and earnings: a test of competing predictions. J Socio-Econ 24(4):571-584. doi:10.1016/1053-5357(95)90003-9. http://dx.doi.org/10.1016/10535357(95)90003-9

Kelliher C, Anderson D (2010) Doing more with less? Flexible working practices and the intensification of work. Human Relations 63(1):83-106. doi:10.1177/0018726709349199. http://dx.doi.org/10.1177/0018726709349199

Lowen A, Sicilian P (2009) "Family-friendly" fringe benefits and the gender wage gap. J Labor Res 30(2):101-119. doi:10.1007/s12122-008-9046-1. http://dx.doi.org/10.1007/s12122-008-9046-1

Manning A (2003) The real thin theory: monopsony in modern labour markets. Labour Econ 10(2):105-131. doi:10.1016/S0927-5371(03)00018-6. http://www.sciencedirect.com/science/article/pii/S0927537103000186

Noonan MC, Glass JL (2012) The hard truth about telecommuting. Mon Labor Rev 135(6):38-45. http://www.bls.gov/ opub/mlr/2012/06/art3full.pdf

Oi W (1976) Residential location and labor supply. J Polit Econ 84(4):S221-S238. doi:10.2307/1831110. http://www.jstor. org/stable/1831110

Peters P, van der Lippe T (2007) The time-pressure reducing potential of telehomeworking: the Dutch case. Int J Human Resource Manag 18(3):430-447. doi:10.1080/09585190601167730. http://dx.doi.org/10.1080/09585190601167730

Peters P, den Dulk L, van der Lippe T (2009) The effects of time-spatial flexibility and new working conditions on employees' work-life balance: the Dutch case. CWF 12(3):279-297. doi:10.1080/13668800902968907. http://dx.doi. org/10.1080/13668800902968907

Plantenga J (2003) Changing work and life patterns: examples of new working-time arrangements in the European member states(Giele JZ, Holst E, eds.). Elsevier, Oxford. http://dx.doi.org/10.1016/S1040-2608(03)08006-7

Possenriede D, Plantenga J (2014) Temporal and locational flexibility of work, working-time fit, and job satisfaction. IZA Discussion Paper 8436, Institute for the Study of Labor (IZA), Bonn. http://ftp.iza.org/dp8436.pdf

Possenriede D, Hassink WHJ, Plantenga J (2014) Does temporal and locational flexibility of work reduce absenteeism. TKI Discussion Paper 14-09, Utrecht University School of Economics, Utrecht. http://hdl.handle.net/1874/298963, universiteit Utrecht

Rau B (2003) Flexible work arrangements(Kossek EE, Pitt-Catsouphes M, eds.). Sloan Work and Family Research Network, Chestnut Hill, MA. http://repo.library.upenn.edu/storage/content/2/h94f69es38006k6s/1/ Flexible_Work_Arrangements.pdf

Rürup B, Gruescu S (2005) Familienorientierte Arbeitszeitmuster - Neue Wege zu Wachstum und Beschäftigung. Bundesministerium für Familien, Senioren, Frauen und Jugend, Berlin. http://www.bmfsfj.de/RedaktionBMFSFJ/ Abteilung2/Pdf-Anlagen/familienorientierte-arbeitszeitmuster.pdf

Smulders P, Kraan K, Pot F (2011) Telewerkers vormen een elite. Economisch Statistische Berichten 96(4616):493-495. http://www.economie.nl/artikel/telewerkers-vormen-een-elite

Sociaal-Economische Raad (2011) Tijden van de samenleving: Slimmer organiseren van tijd en plaats van arbeid en dienstverlening. Advice 2011/06, Sociaal-Economische Raad, Den Haag. http://www.ser.nl/ /media/DB_Adviezen/ 2010_2019/2011/b29686.ashx

Sociaal en Cultureel Planbureau (SCP) (2015) Arbeidsaanbodpanel 1985 t/m 2012. DANS doi:10.17026/dans-x8q-46p7. http://dx.doi.org/10.17026/dans-x8q-46p7 
Taskforce DeeltijdPlus (2010) De discussie voorbij. Eindrapport Taskforce DeeltijdPlus. Ministerie van Sociale Zaken en Werkgelegenheid, Den Haag. http://www.rijksoverheid.nl/bestanden/documenten-en-publicaties/kamerstukken/ 2010/04/06/de-discussie-voorbij-eindrapport-taskforce-deeltijdplus/129-2010-3-14091.pdf

Wielers R, Raven D (2013) Part-time work and work norms in the Netherlands. Eur Sociol Rev 29(1):105-113. doi:10.1093/esr/jcr043. http://dx.doi.org/10.1093/esr/jcr043

Winder KL (2009) Flexible scheduling and the gender wage gap. The BE J Econ Anal Policy 9(1). doi:10.2202/1935-1682.2197. http://dx.doi.org/10.2202/1935-1682.2197

Submit your manuscript to a SpringerOpen ${ }^{\circ}$ journal and benefit from:

- Convenient online submission

$\checkmark$ Rigorous peer review

- Immediate publication on acceptance

- Open access: articles freely available online

- High visibility within the field

- Retaining the copyright to your article

Submit your next manuscript at $\boldsymbol{\wedge}$ springeropen.com 